\title{
Review
}

\section{Androgen receptor signaling and mutations in prostate cancer}

\author{
Shahriar Koochekpour \\ Department of Urology and Stanley S. Scott Cancer Center, School of Medicine, Louisiana State University Health \\ Sciences Center, New Orleans, LA 70112, USA
}

\begin{abstract}
Normal and neoplastic growth of the prostate gland are dependent on androgen receptor (AR) expression and function. Androgenic activation of the AR, in association with its coregulatory factors, is the classical pathway that leads to transcriptional activity of AR target genes. Alternatively, cytoplasmic signaling crosstalk of AR by growth factors, neurotrophic peptides, cytokines or nonandrogenic hormones may have important roles in prostate carcinogenesis and in metastatic or androgen-independent (AI) progression of the disease. In addition, cross-modulation by various nuclear transcription factors acting through basal transcriptional machinery could positively or negatively affect the AR or AR target genes expression and activity. Androgen ablation leads to an initial favorable response in a significant number of patients; however, almost invariably patients relapse with an aggressive form of the disease known as castration-resistant or hormone-refractory prostate cancer (PCa). Understanding critical molecular events that lead PCa cells to resist androgen-deprivation therapy is essential in developing successful treatments for hormone-refractory disease. In a significant number of hormone-refractory patients, the AR is overexpressed, mutated or genomically amplified. These genetic alterations maintain an active presence for a highly sensitive AR, which is responsive to androgens, antiandrogens or nonandrogenic hormones and collectively confer a selective growth advantage to PCa cells. This review provides a brief synopsis of the AR structure, AR coregulators, posttranslational modifications of AR, duality of AR function in prostate epithelial and stromal cells, AR-dependent signaling, genetic changes in the form of somatic and germline mutations and their known functional significance in PCa cells and tissues.
\end{abstract}

Asian Journal of Andrology (2010) 12: 639-657. doi: 10.1038/aja.2010.89; published online16 August 2010.

Keywords: androgen receptor, germline, mutation, prostate cancer, signaling, somatic

\section{Introduction}

Androgen receptor (AR) has a central role in the normal growth and development of the prostate gland, in prostate carcinogenesis and androgen-dependent (AD) or androgen-independent (AI) progression of the disease. Functional AR is expressed during

Correspondence to: Dr Shahriar Koochekpour, Department of Urology and Stanley S. Scott Cancer Center, School of Medicine, Louisiana State University Health Sciences Center, 533 Bolivar Street, New Orleans, LA 70112, USA.

Fax: +1-504-568-6888 E-mail: skooch@1suhsc.edu

Received: 27 May $2010 \quad$ Revised: 2 July 2010

Accepted: 14 July $2010 \quad$ Published online: 16 August 2010 various stages of prostate carcinogenesis from the very early stage of prostate intraepithelial neoplasia to organ-confined or locally invasive primary tumors, in metastatic tumor and before or after androgendeprivation therapy (ADT) [1-5]. When activated by the endogenous androgenic ligands, testosterone (T) and dihydrotestosterone (DHT), AR becomes phosphorylated and the ligand-receptor complex translocates into the nucleus, and in association with coregulatory factors, binds to specific genomic DNA (gDNA) sequences in the regulatory regions of AR target genes.

More than 60 years ago, Huggins and Hodges [6] showed the effectiveness of surgical castration in men 
with prostate cancer $(\mathrm{PCa})$. Since that time, hormonal therapy remains as the most effective and widely used palliative method for advanced and/or metastatic PCa. This method leads to a biochemical response in the majority of patients for up to 3 years, but eventually and almost exclusively during therapy, an incurable highly aggressive AI- or hormone-refractory disease will emerge $[7,8]$. Understanding the molecular events leading to AI progression of $\mathrm{PCa}$ is essential for the development of therapeutic strategies aimed at preventing the AR-dependent signaling.

In spite of the maximum androgen blockade, in hormone-refractory $\mathrm{PCa}$ (HRPCa) patients, expression of AR target genes such as prostate-specific antigen (PSA) remains persistently high [9-11]. Although the exact molecular mechanism(s) responsible for the development of AI-PCa are not understood, available data support the significance of the physical presence and activity of AR. In a relatively large number of AIPCa patients, AR is expressed, overexpressed, mutated or amplified $[12,13]$. In addition, several interesting studies provide evidence for AR-dependent and AIsignaling pathways activated by cytokines (for example, interleukin 6 [IL-6], IL-4), polypeptide growth factors (for example, epidermal growth factor [EGF], insulin-like growth factor [IGF-I]), neuropeptides (for example, bombesin), nonandrogenic steroid hormones, antiandrogens (for example, Flutamide) or other trophic agents $[14,15]$. These nonandrogenic factors can regulate AR expression and/or activity through establishment of downstream cytoplasmic signaling crosstalk or cross-modulation by other transcription factors $[11,15,16]$. The net effect of these events could potentially contribute to AI progression of PCa.

Aberrant AR activation in AI-PCa, also could be due to genetic changes in the form of somatic or germline mutations and genomic amplification. These genetic changes lead to AR overexpression, hypersensitive AR resulting from point mutations and promiscuous mutant AR proteins activated by nonandrogenic ligands or growth modulators. Collectively, advanced PCa will acquire the phenotype of oncogenic addiction to AR and continue to grow and resist available therapeutic regimens. This review summarizes the AR structure, AR-dependent cytoplasmic signaling crosstalk and cross-modulation by transcription factors and the most important genetic changes and their functional significance in PCa cells and tissues.

\section{AR structure and signaling}

\subsection{AR structure}

The $A R$ is a nuclear transcription factor and a member of the steroid hormone receptor superfamily of genes, which includes but is not limited to the receptors for estrogen, progesterone, glucocorticoids, mineralocorticoids, vitamin $\mathrm{D}$, retinoic acid and retinoid $\mathrm{X}$. With the exception of the spleen, the $A R$ is abundantly expressed in neuroendocrine and musculoskeletal tissues and the male genitourinary system [17]. The $A R$ gene is located on the X-chromosome at position Xq11-12 and spans $\sim 90 \mathrm{~kb}$ containing eight exons that code for a $\sim 2757$ bp open reading frame and $\sim 919$ amino acids within a $10.6 \mathrm{~kb}$ mRNA. AR expression is expressed in two isoforms: the predominant isoform $\mathrm{B}$ with $110 \mathrm{kDa}$ mass and the less dominant isoform A with $\sim 80 \mathrm{kDa}[18$, 19]. In addition to these two isoforms, a recent report described additional novel AR splice variants designated as AR3, AR4 and AR5 in androgen-insensitive PCa cell lines (see reference [20] for detailed description). The genomic structure of $A R$ has been highly conserved throughout mammalian evolution. Similar to many other steroid receptors, the AR consists of distinct functional motifs organized as the amino-terminal domain (NTD; 555 amino acids coded by exon 1), DNAbinding domain (DBD; 68-amino acid coded by exon 2 and 3), ligand-binding domain (LBD; 295 amino acids coded by exons 4-8), nuclear localization (amino acid 628-657) and AF-1, AF-5 and AF-2 transactivation units encoded by exon 1 and 8 (Figure 1). A hinge region separates LBD from DBD. On the contrary to the very high evolutionary conservation for LBD, DBD and the $\mathrm{N}$-terminal of the hinge fragment, the most variable region is the NTD sequence. This domain is encoded by several regions of highly repetitive DNA sequences, such as CAG and GGC repeats. Similar to other nuclear receptors, the $\mathrm{DBD}$ region of $\mathrm{AR}$ contains nine cysteines, of which eight are linked to two zinc ions, and through the sulfohydryl groups they are organized in two zinc finger domains (Figure 1). The AR-DNA recognition specificity is determined by the first zinc finger and stabilization of the DNA-receptor complex, and receptor dimerization is determined by the second zinc finger.

\subsection{AR coregulators}

After the discovery of first steroid receptor coactivator (SRC-1), over 170 potential AR coregulators have been identified [21]. This growing list of coregulators 


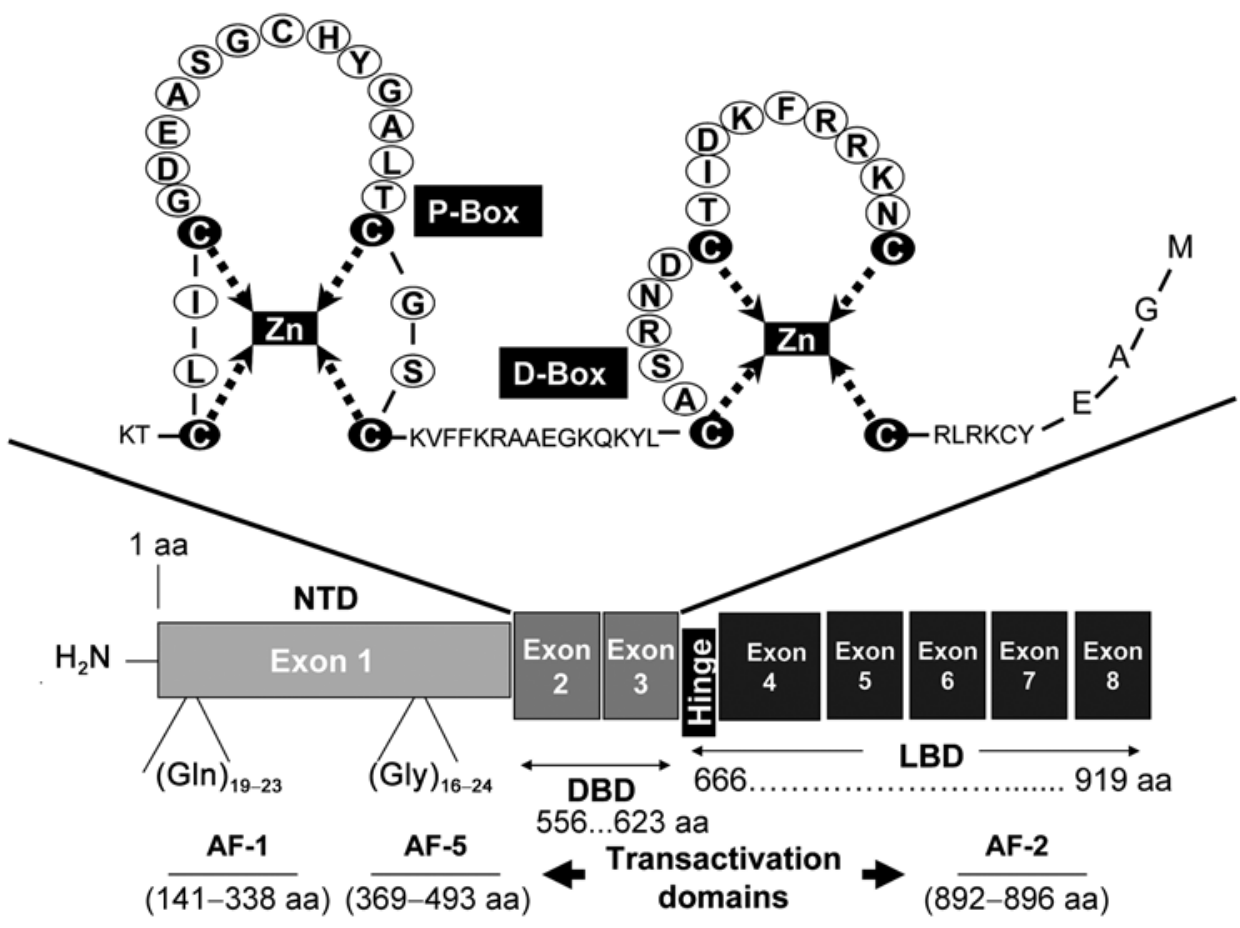

Figure 1. Schematic structure of the androgen receptor $(A R)$ and its two zinc fingers. The exons, three functional domains and the relative positions of the polyglutamine repeats $\left(\mathrm{Gln}_{22}\right)$ and the polyglycine repeat $\left(\mathrm{Gly}_{24}\right)$ in the N-terminus are labeled. The numbers above the domains indicate the amino acid residues. NTD, N-terminal domain; DBD, DNA-binding domain; LBD, ligand-binding domain. AF-1, AF-5, AF-2 are three known transactivation domains in the AR. The two zinc fingers are located in the DNA-binding domain and are crucial structures for $A R$ to bind to AREs. Amino acids of the P- and D-boxes are important for receptor-binding specificity, stabilization of AR-DNA complex and AR dimerization.

has been functionally classified as coactivators or corepressors, or, on the basis of their best recognized primary function, as components of the chromatin remodeling complex, as histone modifiers such as acetyl-transferases and deacetylases, methyltransferases or demethylases, as components of the ubiquitination and proteasomal pathways, as components of the sumoylation pathway, as proteins involved in endocytosis, DNA repair system, splicing and RNA metabolism, or as chaperones and cochaperones, cytoskeletal proteins, signal integrators, transducers, scaffolds and adaptors, or cell cycle or apoptosis regulators [22]. On activation by ligand and nuclear translocation, AR binds to the androgen-response elements (AREs) that may also involve or recruit coregulators to assemble a functional transcriptional complex regulating AR target gene transcription. Changes in the relative expression of AR coregulators have been found to occur with $\mathrm{PCa}$ progression. In addition, AR coregulators may at least partially contribute to differences in AR ligand specificity or its transcriptional activity $[23,24]$.

It has been shown that the expression of SRC-1, TIF-2 and SRC-3, the three members of the SRC or p160 family of coactivators, is increased in $\mathrm{PCa}$ [23, 25]. SRC-1 expression is increased in $50 \%$ of $\mathrm{AD}-\mathrm{PCa}$ samples, as compared with the benign or normal prostate tissues [26]. However, SRC-1 and TIF-2 expression are increased in $63 \%$ of HRPCa [26]. In another study, an increased expression of SRC-3 was associated with increased PCa grade and stage and decreased diseasefree survival [27]. The AR coactivator ARA70 is also overexpressed in PCa samples [28] and after castration in the hormone-refractory CWR22 xenografts [29]. The Cdc25B (cdk-activating phosphatase) was also identified as an AR coactivator, and found not only to be overexpressed in $\mathrm{PCa}$ but also with the highest expression in advanced-stage tumors with high Gleason score [30]. The AR coactivator, Tat interactive protein, $60 \mathrm{kDa}$ (Tip60), was found to be overexpressed on androgen deprivation in the LNCaP cells and CWR22 tumor xenograft [31]. Overall, these studies 
support that $\mathrm{PCa}$ is associated with overexpression of multiple AR coactivators and may contribute to PCa progression. Taking into consideration of the simultaneous involvement of multiple coregulators and their overlapping interaction, additional translational studies are required to determine the contribution of AR coregulators in prostate carcinogenesis and $\mathrm{PCa}$ progression in experimental settings (see reference [22] for a comprehensive review on AR coregulators).

\subsection{Posttranslational modifications of AR}

Steroid receptors can be modified by a variety of posttranslational modifications such as phosphorylation, acetylation, ubiquitinylation and sumoylation. These changes have the potential to affect the receptor stability, subcellular localization, interaction with other proteins within the transcription machinery complex or activity in a cell type- or gene-specific manner. Interestingly, the net effect of AR activity could be affected by crosstalk among different types of posttranslational modifications such as acetylaton and phosphorylation [32]. It is noteworthy that the consequences of posttranslational modifications of AR in prostate carcinogenesis and progression remain to be understood.

\subsubsection{AR phosphorylation and dephosphorylation}

$\mathrm{AR}$ is a nuclear phosphoprotein/transcription factor and in order to exert its transcriptional role after synthesis, it should translocate to the nucleus and remain at a hyperphosphorylated level [15, 33, 34]. Constitutive AR phosphorylation at serine 94 and ligand-induced phosphorylation are reported for serines 16, 81, 256, 309, 424 and $650[33,35]$. In addition, mitogen-activated protein kinases (MAPK) and phosphatidyl inositol-3 kinase/Akt (PI3K/Akt), as the two very important coresignal transduction pathways, are also able to induce AR phosphorylation. On the contrary, AR dephosphorylation will be associated with loss of AR transcriptional activity and inability for nuclear translocation. Protein phosphatase 2A can dephosphorylate AR at NTD, which leads to loss of AR activity [36].

\subsubsection{AR acetylation}

Protein acetylation has a central regulatory role in transcriptional activity of genes. Activity of transcription factors can be also regulated by acetylation. For AR, the KXKK motif of the hinge region is the site of acetylation [37]. Lysine to alanine mutation of the KXKK motif significantly reduces AR activity by dysregulation of stimulation of coactivators in favor of the N-CoR corepressor [38].

In addition, mutations that mimic acetylation increase AR-target gene expression and PCa cell proliferation [39]. A clear example of the crosstalk between acetylation and phosphorylation is provided by the facts that AR acetylation mutants present with decreased phosphorylation and the finding that AR (S94A) phosphorylation mutant is less responsive to p300 stimulation [38]. Another report showed that histone deacetylase inhibitors increase AR activity level without affecting its subcellular localization [40].

\subsubsection{AR ubiquitylation}

AR turnover is not fully understood. Timely degradation of transcription factors is necessary as a control step to sustain transcriptional activity or eliminate it by rapidly degrading the protein. Similar to many other proteins, steroid receptors are also subjected to ubiquitylation. It has been shown that the E3 ubiquitin ligase Mdm2, which promotes polyubiquitylation of AR and its proteasomal degradation, recognizes Akt-dependent phosphorylated serine [41]. In addition, it has been shown that by recruiting the histone deacetylase, Mdm2/AR complex decreases AR-dependent transcriptional activity [42]. On the contrary, it was shown that inhibition of ubiquitylation process and proteasomal degradation of AR by a protease, USP10, functions as an AR coactivator [43].

\subsubsection{AR sumoylation}

This type of posttranslational modification usually affects a small portion of a given protein and leads to covalent binding of a small ubiquitin-like modifier chain on lysine residues embedded in the consensus $\Psi \mathrm{KxE}$ motif. Sumoylation can affect at different levels such as subcellular localization and DNA binding. There is also a possibility for crosstalk between sumoylation and MAP kinase phosphorylation of AR [44]. Sumoylation of AR is hormone dependent and its effect is mainly repressive, but still context dependent. Unlike ubiquitination, sumoylation does not promote protein degradation. In some instances, sumoylation competes with ubquitylation on the lysine residues and functions as an ubiquitin [45]. ARs are sumoylated at lysine 386 and 520 in vivo and mutation of these residues increases AR transactivation, that suggests a role for sumoylation in suppressing AR activity [46]. 


\subsection{AR and cytoplasmic signaling crosstalk}

The growth-promoting effects of androgens are mediated mostly through the AR. Although PCa is heterogeneous in its etiology and progression, androgen signaling through the AR seems to be involved in all aspects of the disease. The binding of the androgenAR complex to AREs involves recruiting coactivators and corepressors to regulate transcription of androgentargeted genes such as PSA. Various members of the steroid receptor superfamily can recognize the same ARE. However, each receptor activates tissuespecific target genes under specific physiological conditions. This receptor-specific tissue response is due to a complex DNA-protein and protein-protein interplay among nonreceptor corregulatory fractors and/or cis-regulatory sequences. After the binding of native ligands, $\mathrm{T}$ and DHT, to the AR and in association with coregulators, the AR will be phosphorylated and translocated to the nucleus, and binds to AREs of the AR target gene promoters that induce their transcriptional activities. Although androgens are important in the maintenance of normal prostate homeostasis, complex interactions between peptide growth factors and other growth modulators regulated either by androgens or by other factors are also required. The transcriptional activity of the AR is important in prostate development, as well as in PCa progression. Androgen binding is the most important stimulus to the AR activity; thus, the PCa hormonal therapy aims to abolish this stimulus. Although hormonal therapy is partly effective, other factors can influence downstream AR-mediated transcription activity. Whether at the level of the AR activation, downstream cytoplasmic signaling crosstalk or nuclear protein cross-modulation, the net effect in patients who have undergone androgen ablation and who have relapsed, is the retention of some androgen-regulated gene activity.

Therefore, it is not surprising that much research into signaling and AR biology in the prostate is directed at addressing this issue. Blockade of peptide growth (trophic) factors or their receptors or the blocking of mutated ARs that are capable of responding to various stimuli may prove effective, and modulation of intermediate signaling factors such as MAPKs or coactivators may allow the suppression of multiple pathways to common DNA targets.

AR transactivation leading to increased endogenous expression of the androgen-responsive PSA gene has also been reported for growth factors such as EGF,
IGF-I, KGF and cytokine IL-6 or through an AI receptor system such as Her2/Neu [11, 14, 47-50]. As AR phosphorylation by itself is not enough to form a functional transcriptional unit, it is also possible that nongenomic signaling may regulate the expression or activity of the AR coregulators along with the AR and, thus, lead to the activation of AR target genes in a ligand-independent manner. Several studies have indicated AR as a common target of MAPK, Akt/protein kinase $\mathrm{B}(\mathrm{PKB})$, protein kinase $\mathrm{A}$ (PKA) or protein kinase $C$ (PKC) [11, 15, 51, 52] (Figure 2). Among these targets, MAPKs present a point of convergence for various signaling pathways. Signaling crosstalk and cross-modulation between the AR and other transcription factors could be responsible for sustained transactivation of androgen-responsive genes. It has been shown that, depending on the upstream ARactivator, the stoichiometry of phosphorylation in the AR is different among various amino acid residues. For example, in response to DHT, a majority ( $>50 \%)$ of the AR populations are phosphorylated at Ser- 81 [33]. The AR function can also be regulated by the Her2/Neu receptor. In LNCaP cells transfected with Her2/Neu, PSA promoter was activated in the absence of androgens but the presence of a functional AR [49]. Additional studies showed Her2/Neu activation of the AR through MAPK signaling pathway, and also that this activation was abolished by MAPK inhibitors [53]. Studies have also led to the hypothesis that AR might be a direct target of Akt/PKB and signal transduction from PI3K/Akt pathway may provide a molecular basis for signaling crosstalk between AR and Akt/PKB [54].

G-protein-coupled receptors serve as the major receptor family for neuropeptides, neurotransmitters and other bioactive peptides [55]. G-proteins share a common pathway for a multiplicity of neurotransmitter receptor functions and have an important role in the regulation of postreceptor levels including the activation of a variety of enzymes, that is, adenylyl cyclase and phospholipase $\mathrm{C}$, which then regulate cell function through the production of second messengers. These second messengers include cyclic AMP (cAMP), diacylglycerol and inositol polyphosphates among others. Then, these molecules will activate the MAPK signaling pathway and several related protein kinases such as PKA that lead to the phosphorylation of various membrane and cytosolic proteins and to the regulation of gene expression by activating a variety of transcription factors $[56,57]$. In addition, PKA 


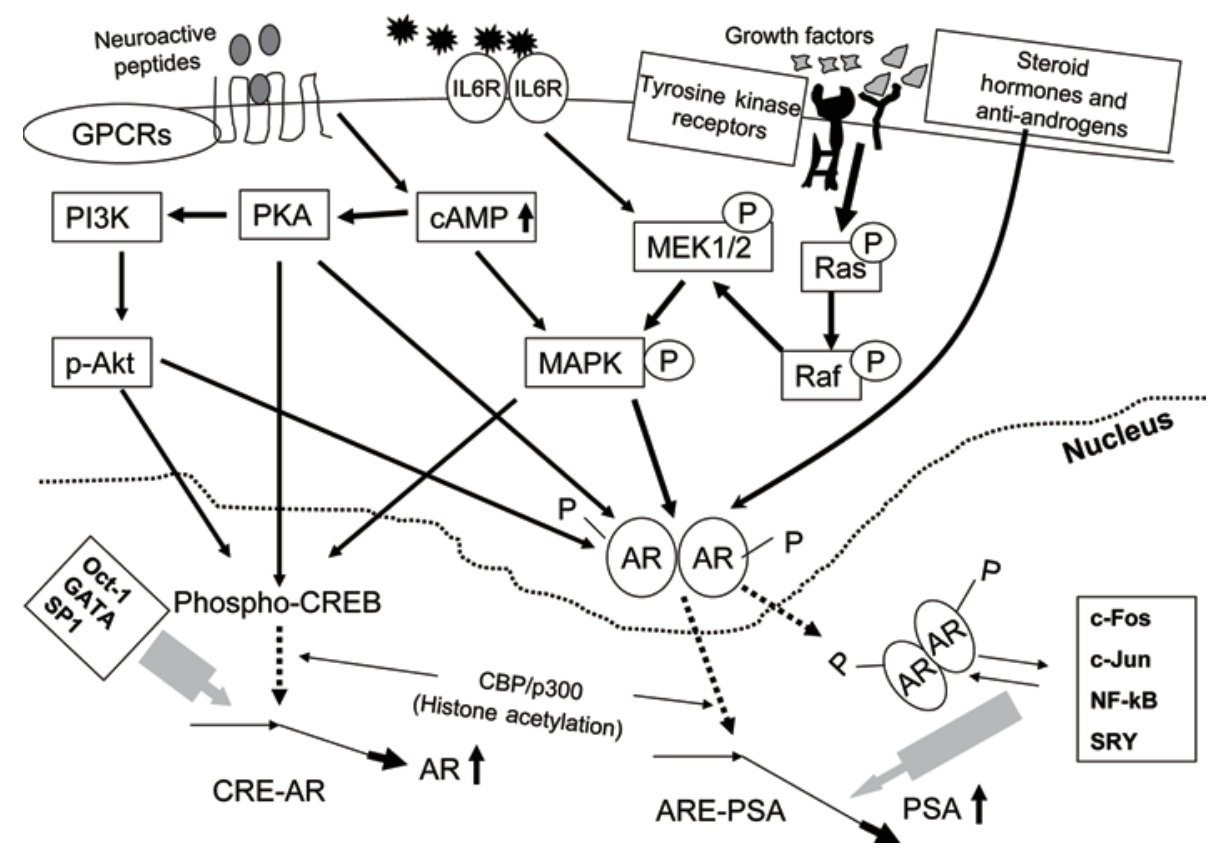

Figure 2. Androgen receptor (AR)-mediated cytoplasmic and nuclear signaling pathways. This diagram simplifies the interactions between the growth factor, cytokines and neuroactive peptides with their cognate receptors that lead to the activation of cytoplasmic kinases (for example, PKA, PI3K) and second messengers (that is, cAMP) and their downstream signaling effectors. Similar to steroid molecules and some antiandrogens, the net effect is the nuclear translocation of phosphorylated $A R$. Most of these pathways are interactive and converge. In addition to cytoplasmic signaling crosstalk, several nuclear transcription factors interacting with each other might serve as positive or negative regulatory agents affecting $A R$ binding and the activity of $A R$ target genes. In addition, several coactivators and corepressors are closely involved for the proper assembly of basal transcription machinery complex regulating the $A R$ activity. As coactivator, $\mathrm{CBP} / \mathrm{p} 300$ bridges AR-mediated signaling with signaling pathways activated by other growth modulators. $\mathrm{P}$, phosporylation; PI3K, phosphatidyl inositol-3 kinase; IL-6R, interleukin-6 receptor; MAPK, mitogen-activated protein kinase; PKA, protein kinase A; MEK1/2, MAPK/ERK kinases; ARE, androgen-response element; PSA, prostate-specific antigen; CRE, cAMP response element; CREB, cAMP response element-binding protein; CBP, CREB-binding protein.

pathway activation leads to phosphorylation of the nuclear transcription factor, cAMP response element (CRE)-binding protein (CREB) at Ser 133. The CREB binds the CRE of its target genes. It has also been shown that CREB-binding protein (CBP) enhances AR-dependent transcription and this AR coactivator integrates androgen-mediated and other signaling pathways [58]. In addition, in androgen-sensitive LNCaP cells, a putative AR-CRE site forms specific and competable protein interactions with CREB [59, 60].

\subsection{AR cross-modulation by nuclear transcription factors}

A network of AR-targeted genes is likely to have a role in driving the growth of AI-PCa potentially through alternative AR activation pathways. Androgen impacts almost every organ in the body and can induce the expression of many genes [23, 61]. However, AREs were identified in only a few gene promoters. Transcription factors are known as constitutive proteins that turn-on or turn-off transcriptional activity of genes. Therefore, they are responsible for bridging various signaling pathways. Cross-modulation among various nuclear transcription factors exists. There are several examples that show that nuclear transcription factors' cross-modulation could also be responsible for the alteration in AR transcriptional activity or androgen target genes expression. It has been shown that androgen induces some of its target genes activity through the other non-ARE consensus sequences including, but not limited to, $c$-fos, $c-J u n, A P-1, S P 1$, $N F_{\kappa} B$, GATA, Oct-1 and SRY [62-83].

c-Fos and c-Jun are ubiquitous transcription factors that are expressed in many different tissues including the prostate. Using HeLa and CV-1 cell lines, Shemshedini et al. [62] have investigated the effect of these transcription factors on transcriptional activity of nuclear steroid receptors including AR. In summary, they have 
shown that c-Fos and c-Jun have different effects on the same steroid receptors in a cell type- and promoterspecific manner; c-Fos can inhibit and c-Jun can prevent or increase receptor-induced transcriptional activity [62].

AP-1, a protein complex whose components are nuclear proteins encoded by $c$-fos and $c$-jun protooncogenes, has been implicated in cell growth, differentiation and development. AP-1 activity is modulated by growth factors, cytokines, oncogenes and tumor promoters such as PKC [84]. Crosstalk between AP-1 and signal transduction pathways of nuclear receptors has been reported for the glucocorticoid receptor (GR), retinoic acid receptor, estrogen receptor, vitamin D3 receptor and thyroid hormone receptor [79-81, 85, 86]. It has been shown that 12-O-tetradecanolylphorbol-13-acetate, which can increase AP-1 levels, could prevent androgen-induced PSA expression in LNCaP cells [63]. Interactions between the AR and AP-1 seems to involve numerous mechanisms including: (1) overlap of the DNA-binding site of the AR with AP-1; (2) a composite DNA-binding site to which both the nuclear receptor and AP-1 bind; and (3) possibly sequestering of a common coactivator such as the CBP [78, 82]. In addition, the interaction between nuclear receptors and AP-1 may be also genespecific, cell-specific and dependant on endogenous levels and/or ratios of Jun to Fos and/or the composition of the AP-1 dimers $[62,83]$. The link between the AP-1 and AR signaling pathway may also regulate the androgen-responsive PSA gene.

The Sp multigene family includes Sp1 and three other genes encoding the Sp2, Sp3 and Sp4 proteins. The consensus binding sequences of these proteins are very similar $[76,87]$. It has been shown that an Sp1binding site within the AR core promoter region may have an important role for the basal activity of the AR promoter $[75,77]$. Recent evidence shows that Sp1, in cooperation with many other factors, can mediate inducible regulation of many genes and it is also involved in the expression of genes related to cell proliferation $[88,89]$. The presence of an Sp1-binding site in the AR gene promoter is an important regulatory element for its expression, and the expression of the two transcription factors (AR and Sp1) can be affected by the same effectors and thereby affect the expression or activity of their downstream target genes (for example, PSA).

$\mathrm{NF}_{\kappa} \mathrm{B} / \mathrm{RelA}$ (p65) is one of the two major members of $\mathrm{NF}_{\kappa} \mathrm{B}$ family of transcription factors. $\mathrm{p} 65-\mathrm{NF}_{\kappa} \mathrm{B}$ is a ubiquitous transcription factor that has a critical role in antiinflammatory responses and programmed-cell death (apoptosis). Palvimo et al. [64], have examined the cross-modulation between $\mathrm{NF}_{\kappa} \mathrm{B}$ and $\mathrm{AR}$ by using the Cos- 1 cell line and transient transfection assays with androgen- and $\mathrm{NF}_{\kappa \mathrm{B}}$-regulated gene. In Cos- 1 cells, increased expression of $\mathrm{p} 65-\mathrm{NF} \kappa \mathrm{B}$ suppressed $\mathrm{AR}$ mediated transactivation in a dose-dependent manner. On the contrary, $\mathrm{p} 65-\mathrm{NF}_{\kappa} \mathrm{B}$ transcriptional activity can be inhibited by the AR and the presence of androgens [64].

The GATA transcription factor family consists of six homologous members containing two highly conserved zinc finger DBDs that recognize the consensus sequence (T/A)GAT(T/A)(A/G) [65, 66]. The expression of GATA-2 and -6 in LNCaP, GATA-3 and -6 in PC-3, GATA-2 in DU-145 cells and GATA-2 and -3 in mouse and human normal and malignant prostates has been reported [67]. In addition, six GATA sites, which flank the $A R E$-III in the far upstream PSA enhancer, are required for optimal PSA expression and stimulation by androgen $[68,90-92]$.

The ubiquitous octamer transcription factor- 1 (Oct-1) is a compelling candidate for corregulation with AR $[69,70]$, in part because Oct-1 interacts in numerous and different manners with GRs. In addition, Oct- 1 is also involved in the regulation of a wide variety of genes [93]. Previous studies have shown that Oct-1 can interact positively or negatively with several nuclear receptors and in a promoter-specific manner. For example, with the mouse mammary tumor virus and gonadotropin-releasing hormone promoters [71, 94], binding of both GR and Oct-1 is required for transactivation. Studies have also shown that the AR interacts physically and functionally with Oct-1 in a DNA-dependent manner [69, 70].

The SRY transcription factor is expressed in the human embryonic urogenital sinus, in adult tissues including adult testis and prostate epithelium, as well as in PCa cell lines [72, 73, 95]. LNCaP cotransfection experiments with AR and SRY expression vectors and a luciferase reporter gene showed that the strong stimulation of PSA by AR in the presence of DHT was markedly repressed when cells were cotransfected with SRY [74]. The SRY repression of the AR transcriptional activity does not require SRY binding to consensus cis-elements. This study also showed that interaction between SRY and the AR was mediated by their respective DBDs and that resulted in the repression of ligand-stimulated AR transcriptional activity on a series of AR target genes. 
2.6 Duality of AR function in prostate epithelial and stromal cells and HRPCa

Normal and neoplastic growth and progression of prostate gland is AR dependent. This fact serves and remains as the basis for ADT. Surgical or chemical castration initially result in a satisfactory treatment response rate in up to $80 \%$ of patients [96] for up to 2 years, but eventually fails, and $\mathrm{PCa}$ progresses to AI- or hormone-refractory incurable state with longdistant metastasis and significant decline of quality of life with the associated side-effects due to male hormone deprivation $[97,98]$. It is also known that AR expression and function are not lost in ADT.

Several studies have provided evidence that androgen replacement therapy (ART) of a selected group of patients who have undergone chemical or surgical castration improved the quality of life, with some biochemical improvement and little or no adverse effect on disease progression [99-102]. The combination of available clinical data on ADT and ART has provided the basis to support a hypothesis for dual personality of AR and postreceptor signaling that is not only dependent on prostate cells (epithelial versus mesenchymal) but also could be patient specific. Interestingly, this wellrationalized hypothesis is supported by studies on tumor-sublines coexisted and isolated from a primary PCa that showed differential response to androgen-AR signals after their orthotopic xenograft establishment in androgen-supplemented versus castrated nonobese diabetic/severe combined immunodeficient (Nod/ SCID) mice [103]. Additional support for celldependent differential androgen-AR signaling was provided by selective knockdown of AR in epithelial and stromal cells of the prostate followed by orthotopic implantation of PCa cell lines with AR overexpression or knockdown. These studies led to very interesting conclusions that AR expression in stromal cells serves as a promoter of PCa growth and metastasis, a survival factor for PCa epithelial luminal cells and as a suppressor for PCa basal intermediate cell growth and metastasis [103].

\section{Genetic alterations in AR}

AR expression can be heterogeneous in $\mathrm{PCa}$, which may reflect genetic instability (for example, mutation) at different stages of the disease and might serve as a prerequisite event for disease aggressiveness. Structural and functional AR abnormalities could explain why $\mathrm{PCa}$ cells resist hormonal ablation and grow in an androgendepleted environment. On the basis of the nature of genetic changes, several mechanisms simultaneously may contribute to the loss of androgen dependence. In addition to cytoplasmic signaling crosstalk and cross-modulation by various transcription factors, $\mathrm{AI}$ progression of $\mathrm{PCa}$ may result from genetic changes in the AR.

Genetic alterations of the AR have been proposed for metastatic or AI progression of PCa including: (1) genomic amplification of AR, (2) hypersensitive AR resulting from point mutations, (3) promiscuous mutant AR protein activated by nonandrogenic ligands and (4) $A R$-polymorphisms changing the response to androgen (for example, poly-CAG repeat) [104].

\subsection{Somatic mutations of AR in PCa}

A major advancement of genetic research in recent years has been the explosion of genome-wide association studies in the literature from different investigators and laboratories [105]. The completion of the reference human genome sequence and its subsequent comparison across different human sub-populations, has identified millions of genetic polymorphisms that differ between different individuals, families and ethnic groups [70]. Somatic genetic alterations can cause differences in histopathology, gene expression and gene amplifications and deletions. The interaction between germline genetic variations (for example, single-nucleotide polymorphisms (SNPs), copy number variants, mini and microsatellites) and somatic alterations can influence the clinical outcome of cancer.

Several studies in Caucasian patients have addressed the frequency of AR mutations in primary organconfined, advanced or metastatic tumors before and after hormonal therapy and their disease relevance [106].

The $A R$ gene is the most mutated type of the steroid receptor. So far, more than 660 mutations of $A R$ have been reported, most of which led to different nonmalignant clinical categories of androgeninsensitivity syndrome [21]. Overall, $A R$ mutations in Caucasian patients are rarely found in untreated localized PCa $(<2 \%)$, but are detected at a high frequency in hormone-refractory, androgen-ablated and metastatic tumors $[21,106]$. The frequency of the $A R$ mutation varies greatly among different studies, up to $25 \%$ in $\mathrm{AD}$ tumors and up to $50 \%$ in metastatic hormone-refractory tumors [21]. Such differences in the reported incidence of AR mutation might be attributed to variability in 
the analytical methodology for the detection of AR mutations, tissue sampling, clinicohistopathological history and the inherent heterogeneity of $\mathrm{PCa}$. Importantly, there is the lack of comparable information in these studies regarding the African-American population (Table 1). The gain-of-function $A R$ mutations in $\mathrm{PCa}$ is detected in different functional domains and rarely in 5'- and 3'-untranslated regions (UTRs) of the gene [21]. Most of these mutations are single base substitutions that directly or indirectly affect AR function (Table 2). About $49 \%$ of the mutations are located in the LBD, $37 \%$ at the NTD and $7 \%$ at DBD.

Table 1. Androgen receptor $(A R)$ gene mutation and amplification in prostate cancer patients.

\begin{tabular}{|c|c|c|c|c|c|c|}
\hline Study No. & $\begin{array}{c}\text { No. of cases } \\
\text { studied }\end{array}$ & $\begin{array}{c}\text { No. of cases } \\
\text { with mutation }\end{array}$ & $\begin{array}{c}\text { No. of cases with } \\
\text { amplification }\end{array}$ & Frequency $(\%)$ & $\begin{array}{c}\text { Androgen } \\
\text { dependence }\end{array}$ & $\begin{array}{c}\text { Reference } \\
\text { No. }\end{array}$ \\
\hline 1 & 40 & 1 & 0 & 3 & HS & {$[163]$} \\
\hline 2 & 26 & 1 & 0 & 4 & HS & [164] \\
\hline 3 & 24 & 6 & 0 & 25 & HS & [108] \\
\hline 4 & 31 & 1 & 0 & 3 & HS & [133] \\
\hline 5 & 36 & 5 & 0 & 14 & HS & {$[165]$} \\
\hline 6 & 54 & 1 & 15 & 28 & HR & [136] \\
\hline 7 & 45 & 3 & 0 & 7 & HS & [166] \\
\hline 8 & 21 & 5 & 0 & 24 & HS & {$[167]$} \\
\hline 9 & 25 & 11 & 0 & 44 & HS & [13] \\
\hline 10 & 23 & 1 & 0 & 4 & HS & [168] \\
\hline 11 & 30 & 0 & 0 & 0 & HS & [109] \\
\hline 12 & 21 & 7 & 4 & 52 & HR & [137] \\
\hline 13 & 16 & 5 & 0 & 31 & HR & [169] \\
\hline 14 & 48 & 5 & 0 & 10 & HR & {$[170]$} \\
\hline 15 & 11 & 4 & 0 & 36 & HR & [139] \\
\hline 16 & 10 & 1 & 0 & 10 & HR & [171] \\
\hline 17 & 18 & 0 & 9 & 50 & HR & [138] \\
\hline 18 & 18 & 0 & 10 & 56 & HR & [140] \\
\hline 19 & 13 & 0 & 4 & 31 & HR & {$[12]$} \\
\hline 20 & 20 & 0 & 3 & 15 & HR & [141] \\
\hline 21 & 77 & 0 & 10 & 13 & HR & {$[172]$} \\
\hline 22 & 5 & 0 & 1 & 20 & HR & [142] \\
\hline 23 & 23 & 0 & 7 & 0 & HR & [144] \\
\hline 24 & 18 & 0 & 0 & 0 & $\mathrm{HR}$ & [173] \\
\hline 25 & 7 & 1 & 0 & 14 & Met-HR & [174] \\
\hline 26 & 10 & 5 & 0 & 50 & Met-HR & [175] \\
\hline 27 & 32 & 2 & 0 & 6 & HR & [176] \\
\hline
\end{tabular}

Abbreviations: HR, hormone refractory; HS, hormone sensitive; Met, metastatic.

Table 2. Distribution of gain-of-function mutation of androgen receptor $(A R)$ in prostate cancer ${ }^{1}$.

\begin{tabular}{lcccc}
\hline Type of mutation & Percentage & NTD (37\%) & DBD (7\%) & LBD (49\%) \\
\hline Single base substitution & 87 & 25 & 6 & 38 \\
Premature termination & 3 & 1 & 0 & 2 \\
Deletion & 7 & 5 & 0 & 1 \\
Insertion & 2 & 0 & 0 & 0 \\
\hline
\end{tabular}

Abbreviations: DBD, DNA-binding domain; LBD, ligand-binding domain; NTD, N-terminal domain.

${ }^{1}$ Mutations are rarely detected at hinge region, splice site, intron and UTRs. http://www.mcgill.ca/androgendb [21]. 
3.2 Somatic AR mutation in in vitro and in vivo $P C a$ model systems

\subsubsection{Human PCa cell lines}

The functional significance of the AR mutation in $\mathrm{PCa}$ is represented in the $\mathrm{AD}$ cell line, $\mathrm{LNCaP}$, derived from a lymph node metastasis of a hormone-refractory patient [107]. In this cell line, the $A R$ gene is mutated at codon 877 (Thr to Ala) of the LBD region [108, 109]. Because of this mutation, the growth of LNCaP is stimulated in vitro not only by androgens but also by nonandrogenic steroids (for example, estrogens, estradiol, progesterone) and antiandrogens (for example, flutamide) (Table 3).

The 22RV1 cell line is an AI-PCa cell line. This cell line was established from CWR22R, a PCa xenograft that was serially inoculated in mice after castration-induced regression and relapse of parental, hormone-dependent CWR22 xeongraft [110]. An early report on this cell line showed the presence of AR mutation at codon H874 (His to Tyr), which is located slightly away from the steroid-binding pocket [111]. This cell line remains responsive to androgens and shows a weak growth response. AR relative binding to natural steroid hormones was estimated as DHT $>$ T $>$ estradiol $>$ progesterone. It was shown that DHT and T upregulated several androgen-regulated genes within $48 \mathrm{~h}$ of treatment [111]. In addition to these findings, a recent report has also indicated the presence of a novel truncated AR mutant, few premRNA splicing variants and a mutant AR that lacks exon 3 tandem duplication in the 22RV1 cell line [112].

The E006AA cell line was established from the prostate tissue of a 50-year-old African-American patient who underwent a bilateral radical retropubic prostatectomy for clinically localized PCa [113]. Clinical and histopathological examination revealed a PSA-positive tumor with Gleason $6(3+3)$ and $\mathrm{T}_{2 \mathrm{a}} \mathrm{N}_{0} \mathrm{M}_{0}$. Recent investigations have revealed that these cells have shown $\mathrm{X}$-chromosome duplication, $A R$ gene amplification and somatic S599G mutation located in the DBD [114, 115]. In addition, knocking down endogenous AR or the ectopic expression of wild-type AR did not affect E006AA cell proliferation [114]. Furthermore, E006AA cells were not responsive to androgens or antiandrogens. On the contrary to current

Table 3. Genetic alterations of androgen receptor $(A R)$ in frequently used prostate cancer cell lines.

\begin{tabular}{|c|c|c|c|c|c|c|c|}
\hline Cell line & Source & AR mutation & Site & Hormone response & $\begin{array}{l}\text { Androgen- } \\
\text { dependence }\end{array}$ & $\begin{array}{l}\text { Ethnic } \\
\text { origin }\end{array}$ & $\begin{array}{c}\text { Reference } \\
\text { No. }\end{array}$ \\
\hline LNCaP & $\begin{array}{l}\text { LN-Met/ } \\
\text { HR-patient }\end{array}$ & T877A & LBD & $\begin{array}{l}\text { DHT Estradiol } \\
\text { Progesterone } \\
\text { Flutamide }\end{array}$ & $\mathrm{AD}$ & $\mathrm{CA}$ & {$[149,150]$} \\
\hline $\begin{array}{l}\text { 22RV1 } \\
\text { (CWR22Rv1) }\end{array}$ & $\begin{array}{l}\text { HS-CWR22R } \\
\text { xenograft }\end{array}$ & $\begin{array}{l}\text { a) H874T } \\
\text { b) H874Y } \\
\text { c) Exon } 3 \text { tandem } \\
\text { duplication } \\
\text { d) Deletion of Exon } 3 \\
\text { tandem duplication } \\
\text { e) Several nonsense } \\
\text { mutants (AR variants) }\end{array}$ & $\begin{array}{l}\mathrm{LBD}^{\mathrm{a}} \\
\mathrm{DBD}\end{array}$ & $\begin{array}{l}\text { Weakly responsive } \\
\text { to DHT for growth }\end{array}$ & AI & $\mathrm{CA}$ & {$[111,112]$} \\
\hline $\begin{array}{l}\text { CWR22 } \\
\text { (CWR-R1) }\end{array}$ & $\begin{array}{l}\text { Recurrent CWR22 } \\
\text { xenograft }\end{array}$ & H874Y & LBD & $\begin{array}{l}\text { Strongly responsive } \\
\text { to DHT }\end{array}$ & AI & $\mathrm{CA}$ & {$[176]$} \\
\hline E006AA & $\begin{array}{l}\text { HS-patient } \\
\text { Organ confined }\end{array}$ & S599G & DBD & Nonresponsive & AI & AA & {$[114,115]$} \\
\hline MDA-PCa2a & HR-patient & T877A & LBD & DHT & AI & AA & {$[116,177]$} \\
\hline MDA-PCa2b & Bone-met & L701H & LBD & GCs & & & \\
\hline
\end{tabular}

Abbreviations: AA, African American; AD, androgen dependent; AI, androgen independent; AR, androgen receptor; CA, Caucasian American; DBD, DNA-binding domain; DHT, dihydrotestosterone; GCs, glucocorticoids; HR, hormone refractory; HS, hormone sensitive; LBD, ligand-binding domain; LN, lymph node; met, metastasis.

an-frame tandem duplication of the exon 3 encoding the second zinc finger of the DBD. 
belief about metastatic and/or hormone-refractory tumors, this cell line might represent an example for a group of $\mathrm{PCa}$ that presents with loss-of-function AR mutation (in terms of proliferative response to androgens) in hormone-naïve patients [114]. These findings may represent a new clinical entity in which aggressive hormonal or antiAR therapies might be ineffective. In addition, it might be an evidence for the presence of AR mutation from the very early stage of $\mathrm{PCa}$. It remains to be understood whether such genetic alterations in AR represent a common phenomenon or that limited to $\mathrm{PCa}$ in the African-American population.

The MDA-PCa $2 \mathrm{a}$ and $2 \mathrm{~b}$ cell lines were derived from a bone metastatic tumor after castration in an African-American patient. The AR in these cell lines presented with $\mathrm{T} 877 \mathrm{~A}$ and $\mathrm{L} 701 \mathrm{H}$ mutations in LBD region [116]. The double mutant $A R$ was found with (a) reduced affinity for androgens, (b) increased affinity for glucocorticoids and (c) synergistic enhancement for glucocorticoids [116].

\subsubsection{Spontaneous AR mutations in intact-and castrated-TRAMP mice}

The transgenic adenocarcinoma of the mouse prostate (TRAMP), is a well-known autochthonous animal model of PCa that was developed in an effort to examine the critical events in the progression of this disease $[117,118]$. The TRAMP model provides a better understanding of the natural, pathobiological history of PCa with respect to temporal changes in the AR gene. Using cDNA cloning of a single-stranded conformational polymorphism, Han et al. [119] have shown the potential for occurrence of spontaneous somatic mutations in AR and the influence of hormonal deprivation on this phenotype in prostate tumors in TRAMP mice. In general, they discovered 15 somatic AR mutations in 8 TRAMP mice between 24 and 29 weeks of age. Nine of these mutations were discovered in prostate tumors of castrated mice and six in intact mice. All of these mutations were base substitutions (10 missense and five silent mutations). Interestingly, but not surprisingly, nine out of 15 mutations occurred in four mice castrated at 12 weeks of age and seven out of nine mutations were localized in the AR transactivation domain. However, the mutations in intact mice were localized at LBD of AR. In castrated mice, two had triple mutant and one double mutant, and only one mouse presented with a single mutation. This study clearly showed not only the high incidence of spontaneous AR mutations but also provided an independent proof of principle that changes in the hormonal environment serve as a major driving force for induction and/or selection of spontaneous somatic mutations that ultimately may provide a growth advantage to PCa cells.

\subsection{Germline AR mutation and PCa}

Germline variations may result in differences among individuals in drug metabolizing activities, cancer pathways and development of distinct molecular subtypes of cancer. Currently, the unequivocally identified risk factors for $\mathrm{PCa}$ are age, ethnic origin and a familial history of the disease. Familial types of PCa with at least two first-degree relatives affected account for $20 \%$ of cases. Hereditary transmission, compatible with Mendellian inheritance, accounts for $50 \%$ of cases. Most other familial forms and sporadic cases involve genetic factors, but in a polygenic or multifactorial mode of inheritance [120]. Genetic susceptibility seems to be more significant in younger patients $(<55$ years old). Linkage analyses in families with hereditary PCa have identified several possible susceptibility or genetic predisposition loci suspected to harbor gene mutations conferring an increased PCa risk. These include highly penetrant susceptibility genes such as $H P C 1, H P C 2$ and $C A P B$ [121-124]. In addition, mutations in the $B R C A 1$ and $B R C A 2$ genes and polymorphic variants of candidate genes such as the $5 \alpha$ reductase and vitamin $\mathrm{D}$ receptor have been suggested to influence the risk for $\mathrm{PCa}$ [125-129].

Owing to the large size of the $A R$ gene $(\sim 90 \mathrm{~kb})$, it has not yet been possible or practical to recognize regulatory variants from primary sequence data in largescale studies with sporadic or familial PCa. However, it has been shown that genomic changes in the $A R$ exist in both noncoding and coding sequences in the form of polymorphism of homopolymeric CAG and GGC repeat lengths, SNPs (for example, rs192696, rs1926927), several silent mutations (for example, $\mathrm{G}>\mathrm{A}, \mathrm{A}>\mathrm{G}, \mathrm{C}>\mathrm{T}$, $\mathrm{T}>\mathrm{C}$ ) and missense mutations [129-131].

Unlike somatic mutations, germline $A R$ mutations are rarely identified. The $\mathrm{R} 726 \mathrm{~L}$ mutation was reported only in Finnish patients with sporadic or familial $\mathrm{PCa}$ $[130,132]$. Additional reports include two unrelated PCa patients with G2T and C214A mutations within the 5'-UTR (noncoding) region of the $A R$ [131]. One final report showed the AR-Q798E mutation in both $\mathrm{PCa}$ tissue and gDNA of a patient [133].

Using exon-specific PCR, bi-directional automated 
sequencing and restriction enzyme genotyping, we evaluated the possibility of genomic changes in the $A R$ in African Americans and Caucasian families with a history of familial PCa defined as equal or more than three patients with $\mathrm{PCa}$ [134]. We screened the $A R$ coding region in $60 \mathrm{PCa}$ cases from 15 AfricanAmerican and 15 Caucasian families with a history of familial PCa. In one of the African-American families, we identified a novel germline $A R$ missense mutation (AR-A1675T [T559S]) in three siblings with early-onset $\mathrm{PCa}$, referring to the $\mathrm{X}$-linked transmission pattern (Figure 3). So far, this has been the first reported germline mutation of the AR in African Americans with a history of familial PCa. The alignment of amino acid sequences of the human AR before and after the $A R$-A $1675 \mathrm{~T}$ (T559S) position showed that the mutant amino acid is located in the $\mathrm{N}$-terminal portion of the DBD that is highly conserved and showed $100 \%$ homology with mouse, rat and monkey. Our investigation of gDNA obtained from 150 normal unrelated individuals (75 African Americans and 75 Caucasians) from the same geographic location (that is, New Orleans, LA, USA) excluded the possibility for AR-A1675T as a polymorphic variant. The localization of the T559S mutation in the DBD makes it a likely candidate affecting the AR-binding affinity to its target genes or its response to androgens, nonandrogenic steroids or antiandrogens. Future large-scale studies using genome-wide association or expression array analysis may determine the genetic profiles or 'signatures' for population-attributable disease risk or aggressiveness for PCa.

\subsection{Genomic amplification of $A R$ in $P C a$}

Amplification of the AR has been proposed as one of the mechanisms for AI progression of PCa after surgical or chemical castration. In most cases, it leads to an overexpression of the AR and hypersensitivity to androgenic ligands. The first evidence of a genomic amplification of the AR in clinical samples was presented by Visakorpi et al. [135] while searching for the commonly amplified genes in hormonerefractory tumors. They have discovered that the $A R$ gene is amplified in 305 of hormone-refractory tumors after therapy. This observation was independently verified by several other investigators in hormonerefractory patients [12, 136-144]. It is not surprising that hormone-refractory patients with AR amplification respond at a higher rate to the second-line maximal androgen blockade, as compared with those without amplification [139]. Together, these findings may support the hypothesis that ADT through an unknown molecular mechanism induces genomic amplification of AR or select subgroup(s) of PCa cells with amplified

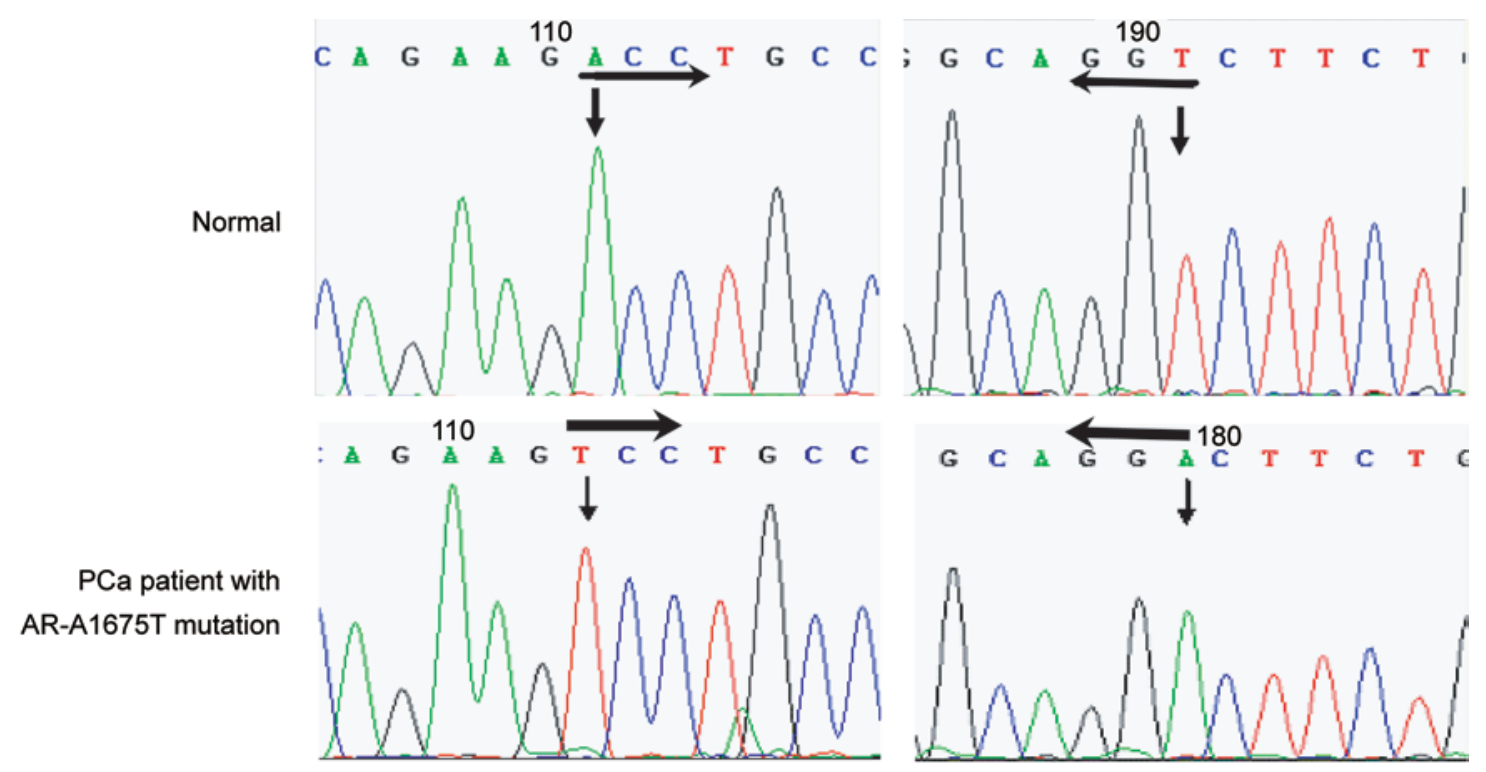

Figure 3. Germline AR-A1675T mutation in a prostate cancer patient from a high-risk African-American family. Polymerase chain reaction amplification of genomic DNA with androgen receptor $(A R)$ exon-specific primers revealed the presence of a missense mutation $(\mathrm{A}>\mathrm{T})$, which resulted in Thr $>$ Ser amino acid change at exon 2 of $A R$. A normal male with A-allele is presented as control. $\mathrm{PCa}$, prostate cancer. 
AR from a heterogeneous tumor cell population.

So far, genomic amplification of the AR has been only reported in the E006AA cell line [115]. Using a GeneChip 500K single nucleotide polymorphic (SNP) array (Affymetrix) with an average resolution of $\sim 5.8 \mathrm{~kb}$, AR amplification was observed in the E006AA cell line [115]. The gain of extra copies of the AR in the E006AA cells was further confirmed by fluorescent in situ hybridization in which metaphase analysis showed two copies of the X-centromere, consistent with the previously reported karyotype [115]. This unique combination of the S599G loss-of-function somatic mutation and genomic amplification of the $A R$ in a $\mathrm{PCa}$ cell line derived from a hormonally naïve patient adds additional complexity to the role of the AR in PCa biology and might highlight an uninvestigated paradox in the clinical management of the disease.

\section{Racial differences in AR expression in PCa}

Limited information is available on race and AR expression in benign and malignant prostate tissues. When compared with Caucasians, African-American men are disproportionately and more frequently diagnosed with an earlier age of onset, higher tumor volume, more advanced (aggressive) tumor stage, higher Gleason scores and higher PSA levels [144146]. Such differences may stem from differences in the androgen-AR axis. This led many investigators to study racial differences in serum androgens, polymorphisms of $5 \alpha$-reductase and $A R$-trinucleotide CAG and GGC repeat lengths [120, 144-149]. In one study, AR protein expression was analyzed in benign and malignant prostate tissues obtained from radical prostatectomy specimens of 25 African Americans and 25 Caucasians with localized PCa [148]. Visual scoring method suggested that AR immunostained more intensely in both malignant and benign prostate epithelial nuclei in African-American than in Caucasian samples. In addition, automated digital color video image analyses were used to measure the percentage of positive nuclei and the intensity of expression in each nucleus. In African Americans, when compared with Caucasians, malignant PCa cells were $27 \%$ more likely stained for AR $(P=0.005)$, and among immunopositive benign prostate cells, AR protein expression was $81 \%$ greater $(P=0.002)$ [148]. As indicated in Table 1 , with exception to one study including $12 \mathrm{HRPCa}$ (Taplin et al. [170]), all studies investigated Caucasians
PCa. Taking into consideration the important role of the AR in prostate carcinogenesis and progression, comparable studies in African Americans are needed to determine the incidence of $A R$ mutations, and the contribution of these mutations to $\mathrm{PCa}$ progression and aggressiveness and their clinical and histopathological significance in African Americans with PCa.

\section{AR mutation and AR activity}

Activation of mutant ARs by alternative steroids and/ or antiandrogens may provide a growth advantage to $\mathrm{PCa}$ cells expressing the mutant receptor. Determining the function of these mutant ARs is important for understanding their role in the progression of $\mathrm{AD}$ tumors and the development of AI-PCa. There may be a broad steroid specificity of the mutant AR compared with the wild-type receptor in the transactivation of the androgen-responsive genes. Mutations in the $A R$ can alter either the hormone-binding affinity, transactivation specificity or both.

Functional analysis of the mutant $A R$ in the past has shown that majority of the $A R$ mutations are gain-of-function type and only a small number of mutations are loss-of-function type [21]. Gain-offunction mutations are expected to either increase the AR expression level, hypersensitize it to lower concentrations of DHT or make it responsive to other steroid hormones. Some of these gain-of-function mutations may show promiscuous activity, being transactivated by nonandrogens. Loss-of-function mutants would not be able to transactivate target genes in the presence of DHT. In addition, some mutant ARs might show weaker responses to androgens compared with the wild-type receptor. Nonandrogenic hormones such as progesterone might confer transactivation property to mutant ARs. Trans-activation function of mutant ARs may have a role in the progression of prostatic carcinoma, as it may still be functionally active in the androgen-ablated patient and responsive to other hormones such as dihydroepiandrosterone and androstenedione, which are accumulated in the prostatic tissue [149]. Mutant ARs might also be transactivated by nonsteroidal antiandrogen hydroxyl-flutamide (OH-F) or bicalutamide [150].

Mutations in the $A R$ can induce structural changes that might lead to an alteration in the hormone-binding and trans-activation specificities of the receptor. For example, the AR in the LNCaP cells has an increased 
binding affinity for estradiol, progesterone and $\mathrm{OH}-\mathrm{F}$ $[149,150]$. These substances also mediate transactivation by the mutant $\mathrm{AR}$ in the $\mathrm{LNCaP}$ cells. The functional activities of various steroidal and nonsteroidal compounds binding to the AR should not be judged by their affinity for the receptor, but rather by the conformational changes they introduce into the receptor molecule. A variety of methods and model systems have been used to investigate a functional significance of AR mutations in prostate and nonprostatic cells. PC-3 and COS-7 cells do not contain endogenous AR and have been used as a model cell line to determine hormone-binding and transcriptional activity of $A R[120-132,134,135,137,138,143-145$, 147-156]. There might be some differences in the activity of exogenously added AR between the two cell types, one being from a monkey kidney fibroblast and the other from a human PCa cell line.

Colorimetric yeast reporter assay has been used to study transactivational activity of mutant AR. The yeast reporter assay is also an attractive, rapid, efficient and inexpensive model. Yeast assays present a well-defined genetic background and allow a highthroughput screening for AR mutations. As yeast does not have steroid receptors or most of their coregulators, it can provide the intrinsic activity of the mutated $A R$ This method has been successfully used to investigate steroid receptor function and for functional analyses of large numbers of AR mutations in $\mathrm{PCa}$ or other type of receptors in mammalian cell system [157-159].

The activity of mutant ARs in the presence or absence of various treatment agents could also be determined by their state of phosphorylation or nuclear translocation using either the immunofluoresence staining with phospho-AR antibody or metabolic radiolabeling assays [160-162].

\section{Conclusions}

AR remains one of the most import nuclear transcription factor from the steroid hormone receptor superfamily of genes. Normal prostate growth and development, prostate carcinogenesis and AI progression of $\mathrm{PCa}$ are dependent on $\mathrm{AR}$ expression and function. As a brief and oversimplified statement, the prostate gland at any state of normal or neoplastic growth is addicted to AR. Alterations in AR structure, expression and signaling could have a determining role in PCa progression toward an incurable AI state. These alterations could be secondary to somatic or germline mutations, presence or absence of nonandrogenic ligands, cytoplasmic signaling crosstalk with other kinases or cross-modulation by other nuclear transcription factors. This review provides a synopsis of the most common events, signaling and mutation that might change the benign or malignant state of the prostate. Although the focus of this review was prostate epithelial cells, we should emphasize that other cellular and acellular elements of the prostate microenvironment have important regulatory roles for AR expression and signaling. Future studies are still required to dissect AR biology, especially in HRPCa. It should be noted that the complex nature of $\mathrm{PCa}$ and its unique and inherent heterogeneity prevent us from predicting whether or not interference with the AR dependency of $\mathrm{PCa}$ can prove to be the final cure.

\section{Acknowledgment}

Data from Dr Koochekpour's laboratory work were supported by NCI Grants R21-CA149137 and R21CA143589-01A1 and in part by NIH-NCRR; 1P20 RR021970 (Augusto Ochoa/Shahriar Koochekpour) and P20MD004817 (Betty Dennis, John Estrada/ Shahriar Koochekpour) grant from the National Center on Minority Health and Health Disparities (NCMHD). Due to space limitations, I was unable to discuss and cite several other important contributions to the subject of this review article. I am indebted to the patients and their families and physicians for contributing to the studies performed in my laboratory. I thank Ms. Jonna Ellis for editorial assistance. This article is dedicated to the citizens of New Orleans, LA, to all the survivors, and in loving memory of those who lost their lives as a result of the devastation from Hurricane Katrina.

\section{Disclaimer}

The content is solely the responsibility of the author and does not necessarily represent the official views of the NCMHD or the National Institutes of Health.

\section{References}

1 Van der Kwast TH, Têtu B. Androgen receptors in untreated and treated prostatic intraepithelial neoplasia. Eur Urol 1996; 30: 265-8.

2 Sadi MV, Walsh PC, Barrack ER. Immunohistochemical study of androgen receptors in metastatic prostate cancer. 
Comparison of receptor content and response to hormonal therapy. Cancer 1991; 67: 3057-64.

3 Tilley WD, Lim-Tio SS, Horsfall DJ, Aspinall JO, Marshall VR, et al. Detection of discrete androgen receptor epitopes in prostate cancer by immunostaining: measurement by color video image analysis. Cancer Res 1994; 54: 4096-102.

4 Hobisch A, Culig Z, Radmayr C, Bartsch G, Klocker H, et al. Distant metastases from prostatic carcinoma express androgen receptor protein. Cancer Res 1995; 55: 3068-72.

5 Hobisch A, Culig Z, Radmayr C, Bartsch G, Klocker H, et al. Androgen receptor status of lymph node metastases from prostate cancer. Prostate 1996; 28: 129-35.

6 Huggins C, Hodges CV. The effect of castration, of estrogen and of androgen injection on serum phosphatases in metastatic carcinoma of the prostate. Cancer Res 1941; 1: 293-7.

7 Palmberg C, Koivisto P, Visakorpi T, Tammela TL. PSA decline is an independent prognostic marker in hormonally treated prostate cancer. Eur Urol 1999; 36: 191-6.

8 Gittes RF. Carcinoma of the prostate. N Engl J Med 1991; 324: 236-45.

9 Arnold JT, Isaacs JT. Mechanisms involved in the progression of androgen-independent prostate cancers: it is not only the cancer cell's fault. Endocr Relat Cancer 2002; 9: 61-73.

10 Denmeade SR, Isaacs JT. A history of prostate cancer treatment. Nat Rev Cancer 2002; 2: 389-96.

11 Feldman BJ, Feldman D. The development of androgenindependent prostate cancer. Nat Rev Cancer 2001; 34-45.

12 Linja MJ,Savinainen KJ, Saramäki OR, Tammela TL, Vessella RL, et al. Amplification and overexpression of androgen receptor gene in hormone-refractory prostate cancer. Cancer Res 2001; 61:3550-5.

13 Tilley WD, Buchanan G, Hickey TE, Bentel JM. Mutations in the androgen receptor gene are associated with progression of human prostate cancer to androgen independence. Clin Cancer Res 1996; 2: 277-85.

14 Culig Z, Bartsch G, Hobisch A. Interleukin-6 regulates androgen receptor activity and prostate cancer cell growth. Mol Cell Endocrinol 2002; 197: 231-8.

15 Grossmann ME, Huang H, Tindall DJ. Androgen receptor signaling in androgen-refractory prostate cancer. J Natl Cancer Inst 2001; 93: 1687-97.

16 Hobisch A, Ramoner R, Fuchs D, Godoy-Tundidor S, Bartsch $\mathrm{G}$, et al. Prostate cancer cells (LNCaP) generated after long-term interleukin 6 (IL-6) treatment express IL-6 and acquire an IL-6 partially resistant phenotype. Clin Cancer Res 2001; 7: 2941-8.

17 O'Malley BW, Yamagata K, Fujiyama S, Ito S, Ueda T, et al. Molecular mechanism of action of a steroid hormone receptor. Recent Prog Horm Res 1991; 47: 1-24.

18 Gao T, McPhaul MJ. Functional activities of the A and $\mathrm{B}$ forms of the human androgen receptor in response to androgen receptor agonists and antagonists. Mol Endocrinol 1998; 12: 654-63.

19 Wilson JD. The promiscuous receptor. Prostate cancer comes of age. N Engl J Med 1995; 332: 1440-1.

20 Guo Z, Yang X, Sun F, Jiang R, Linn DE, Chen H, et al. A novel androgen receptor splice variant is up-regulated during prostate cancer progression and promotes androgen depletion-resistant growth. Cancer Res 2009; 69: 2305-13.

21 Gottlieb B, Beitel LK, Wu JH, Trifiro M. The androgen receptor gene mutations database (ARDB). Hum Mutat 2004; 23: 527-33.

22 Heemers HV, Tindall DJ. Androgen receptor (AR) core- gulators: a diversity of functions converging on and regulating the AR transcriptional complex. Endocr Rev 2007; 28: 778-808.

23 Roy AK, Lavrovsky Y, Song CS, Chen S, Jung MH et al. Regulation of androgen action. Vitam Horm 1999; 55: 309-52.

24 Heinlein CA, Chang C. Androgen receptor (AR) coregulators: an overview. Endocr Rev 2002; 23: 175-200.

25 McKenna NJ, Lanz RB, O’Malley BW. Nuclear receptor coregulators: cellular and molecular biology. Endocr Rev 1999; 20: 321-44.

26 Gregory CW, He B, Johnson RT, Ford OH, Mohler JL, et al. A mechanism for androgen receptor mediated prostate cancer after androgen deprivation therapy. Cancer Res 2000; 61: 4315-9.

27 Gnanapragasam VJ, Leung HY, Pulimood AS, Neal DE, Robson CN. Expression of RAC3, a steroid hormone receptor co-activator in prostate cancer. Br J Cancer 2000; 85: 1928-36.

28 Yeh S, Chang C. Cloning and characterization of a specific coactivator, ARA70, for the androgen receptor in human prostate cells. Proc Natl Acad Sci USA 1996; 93: 5517-21.

29 Gregory CW, Hamil KG, Kim D, Hall SH, Pretlow TG ,et al. Androgen receptor expression in androgen-independent prostate cancer is associated with increased expression of androgen-regulated genes. Cancer Res 1998; 58: 5718-24.

30 Ngan ES, Hashimoto Y, Ma ZQ, Tsai MJ, Tsai SY. Overexpression of $\mathrm{Cdc} 25 \mathrm{~B}$, an androgen receptor coactivator, in prostate cancer. Oncogene 2003; 22: 734-9.

31 Halkidou K, Gnanapragasam VJ, Mehta PB, Logan IR, Brady ME, et al. Expression of Tip60, an androgen receptor coactivator, and its role in prostate cancer development. Oncogene 2003; 22: 2466-77.

32 Faus H, Haendler B. Post-translational modifications of steroid receptors. Biomed Pharmacother 2006; 60: 520-8.

33 Gioeli D, Ficarro SB, Kwiek JJ, Aaronson D, Hancock M, et al. Androgen receptor phosphorylation. Regulation and identification of the phosphorylation sites. J Biol Chem 2002; 277: 29304-14.

34 O'Malley BW, Tsai SY, Bagchi M, Weigel NL, Schrader WT,et al. Molecular mechanism of action of a steroid hormone receptor. Recent Prog Horm Res 1991; 47: 1-24.

35 Wong HY, Burghoorn JA, Van Leeuwen M, De Ruiter PE, Schippers E, et al. Phosphorylation of androgen receptor isoforms. Biochem J 2004; 383: 267-76.

36 Yang CS, Vitto MJ, Busby SA, Garcia BA, Kesler CT, et al. Simian virus 40 small $\mathrm{t}$ antigen mediates conformationdependent transfer of protein phosphatase $2 \mathrm{~A}$ onto the androgen receptor. Mol Cell Biol 2005; 25: 1298-308.

37 Fu M, Wang C, Reutens AT, Wang J, Angeletti RH, et al. p300 and p300/cAMP-response element-binding protein associated factor acetylate the androgen receptor at sites governing hormone-dependent transactivation. J Biol Chem 2000; 275: 20853-60.

38 Fu M, Rao M, Wu K, Wang C, Zhang X, et al. The androgen receptor acetylation site regulates cAMP and AKT but not ERK induced activity. J Biol Chem 2004; 279: 29436-49.

39 Halkidou K, Gnanapragasam VJ, Mehta PB, Logan IR, Brady ME, et al. Expression of Tip60, an androgen receptor coactivator, and its role in prostate cancer development. Oncogene 2003; 22: 2466-77.

40 Korkmaz CG, Frønsdal K, Zhang Y, Lorenzo PI, Saatcioglu $\mathrm{F}$, et al. Potentiation of androgen receptor transcriptional 
activity by inhibition of histone deacetylation-rescue of transcriptionally compromised mutants. J Endocrinol 2004; 182: 377-89.

41 Lin HK, Wang L, Hu YC, Altuwaijri S, Chang C. Phosphorylation dependent ubiquitylation and degradation of androgen receptor by Akt require Mdm2 E3 ligase. EMBO J 2002; 21: 4037-48.

42 Gaughan L, Logan IR, Neal DE, Robson CN. Regulation of androgen receptor and histone deacetylase 1 by $\mathrm{Mdm} 2$ mediated ubiquitylation. Nucleic Acids Res 2005; 33: 13-26.

43 Faus H, Meyer HA, Huber M, Bahr I, Haendler B. The ubiquitinspecific protease USP10 modulates androgen receptor function. Mol Cell Endocrinol 2005; 245: 138-46.

44 Yang SH, Sharrocks AD. Interplay of the SUMO and MAP kinase pathways. Ernst Schering Res Found Workshop 2006; 57: 193-209.

45 Desterro JM, Rodriguez MS, Hay RT. SUMO-1 modification of IkappaBalpha inhibits NF-kappaB activation. Mol Cell 1998; 2: 233-9.

46 Poukka H, Karvonen U, Janne OA, Palvimo JJ. Covalent modification of the androgen receptor by small ubiquitinlike modifier 1 (SUMO-1). Proc Natl Acad Sci USA 2000; 97: $14145-50$.

47 Comuzzi B, Lambrinidis L, Rogatsch H, Godoy-Tundidor $\mathrm{S}$, Knezevic N, et al. The transcriptional co-activator cAMP response element-binding protein-binding protein is expressed in prostate cancer and enhances androgen- and anti-androgen-induced androgen receptor function. Am J Pathol 2003; 162: 233-41.

48 Culig Z, Hobisch A, Bartsch G, Klocker H. Androgen receptor-an update of mechanisms of action in prostate cancer. Urol Res 2000; 28: 211-9.

49 Craft N, Shostak Y, Carey M, Sawyers CL. A mechanism for hormone independent prostate cancer through modulation of androgen receptor signaling by the HER-2/ neu tyrosine kinase. Nat Med 1999; 5: 280-3.

50 Culig Z, Hobisch A, Cronauer MV, Radmayr C, Trapman J, et al. Androgen receptor activation in prostatic tumor cell lines by insulin-like growth factor-I, keratinocyte growth factor, and epidermal growth factor. Cancer Res 1994; 54: 5474-8.

51 Mohler JL, Gaston KE, Moore DT, Schell MJ, Cohen BL, et al. Racial differences in prostate androgen levels in men with clinically localized prostate cancer. J Urol 2004; 171: 2277-80.

52 Nazareth LV, Weigel NL. Activation of the human androgen receptor through a protein kinase A signaling pathway. J Biol Chem 1996; 271: 19900-07.

53 Yeh S, Lin HK, Kang HY, Thin TH, Lin MF, et al. From HER2/Neu signal cascade to androgen receptor and its coactivators: a novel pathway by induction of androgen target genes through MAP kinase in prostate cancer cells. Proc Natl Acad Sci USA 1999; 96: 5458-63.

54 Lin HK, Yeh S, Kang HY, Chang C. Akt suppresses androgen-induced apoptosis by phosphorylating and inhibiting androgen receptor. Proc Natl Acad Sci USA 2001; 98: 7200-5.

55 Woehler A, Ponimaskin EG. G protein-mediated signaling: same receptor, multiple effectors. Curr Mol Pharmacol 2009; 2: $237-48$.

56 Pitcher JA, Freedman NJ, Lefkowitz RJ. G protein-coupled receptor kinases. Ann Rev Biochem 1998; 67: 653-92.

57 Hamm HE. The many faces of $\mathrm{G}$ protein signaling. J Biol Chem 1998; 273: 669-72.

58 Aarnisalo P, Palvimo JJ, Janne OA. CREB-binding protein in androgen receptor-mediated signaling. Proc Natl Acad Sci USA 1998; 95: 2122-7.

59 Mizokami A, Yeh SY, Chang C. Identification of 3',5'-cyclic adenosine monophosphate response element and other cis-acting elements in the human androgen receptor gene promoter. Mol Endocrinol 1994; 8: 77-88.

60 Stubbs AP, Lalani EN, Stamp GW, Hurst H, Abel P. Second messenger up-regulation of androgen receptor gene transcription is absent in androgen insensitive human prostatic carcinoma cell lines, PC-3 and DU-145. FEBS Lett 1996; 383: 237-40.

61 Mooradian AD, Morley JE, Korenman SG. Biological actions of androgens. Endocrinol Rev 1987; 8: 1-28.

62 Shemshedini L, Knauthe R, Sassone-Corsi P, Pornon A, Gronemeyer H. Cell-specific inhibitory and stimulatory effects of Fos and Jun on transcription activation by nuclear receptors. EMBO J 1991; 10: 3839-49.

63 Sato N, Sadar MD, Bruchovsky N, Saatcioglu F, Rennie PS, et al. Androgenic induction of prostate-specific antigen gene is repressed by protein-protein interaction between the androgen receptor and AP-1/c-Jun in the human prostate cancer cell line LNCaP. J Biol Chem 1997; 272: 17485-92.

64 Palvimo JJ, Reinikainen P, Ikonen T, Kallio PJ, Moilanen A, et al. Mutual transcriptional interference between RelA and androgen receptor. J Biol Chem 1996; 271: 24151-6.

65 Simon MC. Gotta have GATA. Nat Genet 1995; 11: 9-11.

66 Weiss MJ, Yu C, Orkin SH. Erythroid-cell-specific properties of transcription factor GATA-1 revealed by phenotypic rescue of a gene-targeted cell line. Mol Cell Biol 1997; 17: 1642-51.

67 Perez-Stable CM, Pozas A, Roos BA. A role for GATA transcription factors in the androgen regulation of the prostatespecific antigen gene enhancer. Mol Cell Endocrinol 2000; 167: 43-53.

68 Pang S, Dannull J, Kaboo R, Xie Y, Tso CL, et al. Identification of positive regulatory element responsible for tissue-specific expression of prostate-specific antigen. Cancer Res 1997; 57: 495-9.

69 Gonzalez MI, Robins DM. Oct-1 preferentially interacts with androgen receptor in a DNA-dependent manner that facilitates recruitment of SRC-1. J Biol Chem 2001; 276: 6420-8.

70 Gonzalez MI, Tovaglieri A, Robins DM. Androgen receptor interactions with Oct-1 and Brn-1 are physically and functionally distinct. Mol Cell Endocrinol 2002; 190: 39-43.

71 Préfontaine GG, Lemieux ME, Giffin W, Schild-Poulter C, Pope $\mathrm{L}$, et al. Recruitment of octamer transcription factors to DNA by glucocorticoid receptor. Mol Cell Biol 1998; 18: 3416-30.

72 Salas-Cortes L, Jaubert F, Barbaux S, Nessmann C, Bono MR, et al. The human SRY protein is present in fetal and adult Sertoli cells and germ cells. Int J Dev Biol 1999; 43: 135-40.

73 Tricoli JV, Yao JL, D'Souza SA, Bracken RB. Detection of sex-region Y (SRY) transcripts in human prostate adenocarcinoma and benign prostatic hypertrophy. Genes Chromosomes Cancer 1993; 8: 28-33.

74 Yuan X, Lu ML, Li T, Balk SP. SRY interacts with and negatively regulates androgen receptor transcriptional activity. J Biol Chem 2001; 276: 46647-54.

75 Oesch-Bartlomowicz B. cAMP-dependent phosphorylation of CYP2B1 as a functional switch for cyclophosphamide activation and its hormonal control in vitro and in vivo. Int $\mathrm{J}$ Cancer 2001; 94: 733-42.

76 Hagen C, Muller S, Beato M, Suske G. Cloning by recognition site screening of two novel GT box binding proteins: a family of Sp1 related genes. Nucleic Acids Res 1992; 20: 5519-25. 
77 Chen S, Supakar PC, Vellanoweth RL, Song CS, Chatterjee $\mathrm{B}$, et al. Functional role of a conformationally flexible homopurine/homopyrimidine domain of the androgen receptor gene promoter interacting with $\mathrm{Sp} 1$ and a pyrimidine single strand DNA-binding protein. Mol Endocrinol 1997; 11: 3-15.

78 Pfahl M. Nuclear receptor/AP-1 interaction. Endocr Rev 1993; 14: 651-8.

79 Jonat C, Rahmsdorf HJ, Park KK, Cato AC, Gebel S. et al. Antitumor promotion and antiinflammation: down-modulation of AP-1 (Fos/Jun) activity by glucocorticoid hormone. Cell 1990; 62: 1189-204.

80 Konig H, Ponta H, Rahamsdorf HJ, Herrlich P. Interference between pathway-specific transcription factors: glucocorticoids antagonize phorbol ester-induced AP-1 activity without altering AP-1 site occupation in vivo. EMBO J 1992; 11: 2241-6.

81 Nicholson RC, Mader S, Nagpal S, Leid M, Rochette-Egly $\mathrm{C}$, et al. Negative regulation of the rat stromelysin gene promoter by retinoic acid is mediated by an AP1 binding site. EMBO J 1990; 9: 4443-54.

82 Kamei Y, Xu L, Heinzel T, Torchia J, Kurokawa R, et al. A CBP integrator complex mediates transcriptional activation and AP-1 inhibition by nuclear receptors. Cell 1996; 85: 403-14.

83 Lucibello FC, Slater EP, Jooss KU, Beato M, Müller R. Mutual transrepression of Fos and the glucocorticoid receptor: involvement of a functional domain in Fos which is absent in FosB. EMBO J 1990; 9: 2827-34.

84 Lupowitz Z, Rimler A, Zisapel N. Evaluation of signal transduction pathways mediating the nuclear exclusion of the androgen receptor by melatonin. Cell Mol Life Sci 2001; 58: 2129-35.

85 Schule R, Umesono K, Mangelsdorf DJ, Bolado J, Pike JW,et al. Jun-Fos and receptors for vitamins $\mathrm{A}$ and $\mathrm{D}$ recognize a common response element in the human osteocalcin gene. Cell 1990; 61: 497-504.

86 Zhang XK, Tran P, Pfahl M. DNA binding and dimerization determinants for thyroid hormone receptor alpha and its interaction with a nuclear protein. Mol Endocrinol 1991; 5: 1909-20.

87 Trojanowska M. Ets factors and regulation of the extracellular matrix. Oncogene 2000; 19: 6464-71.

88 Philipsen S, Suske GA. Tale of three fingers: the family of mammalian Sp/XKLF transcription factors. Nucleic Acid Res 1997; 27: 2991-3000.

89 Alroy I, Soussan L, Seger R, Yarden Y. Neu differentiation factor stimulates phosphorylation and activation of the $\mathrm{Sp} 1$ transcription factor. Mol Cell Biol 1999; 19: 1961-72.

90 Schuur ER, Henderson GA, Kmetec LA, Miller JD, Lamparski HG, et al. Prostate-specific expression is regulated by an upstream enhancer. J Biol Chem 1996; 271: 7043-51.

91 Cleutjens KB, van der Korput HA, van Eekelen CC, van Rooij HC, Faber PW, et al. An androgen response element in a far upstream enhancer region is essential for high, androgenregulated activity of the prostate-specific antigen promoter. Mol Endocrinol 1997; 11: 148-61.

92 Zhang S, Murtha PE, Young CYF. Defining a functional androgen response element in the $5^{\prime}$ far upstream flanking region of the prostate-specific antige gene. Biochem Biophys Res Commun 1997; 231: 784-8.

93 Verrijzer CP, Van der Vliet PC. POU domain transcription factors. Biochim Biophys Acta 1993; 1173: 1-21.

94 Chandran U, DeFranco D. Regulation of gonadotropinreleasing hormone gene transcription. Behav Brain Res 1999;
105: 29-36.

95 Lau YF, Zhang J. Expression analysis of thirty-one Y chromosome genes in human prostate cancer. Mol Carcinog 2000; 27: 308-21.

96 Bruchovsky N. Androgens and antiandrogens. In: Holland JF, Frei E III, Bast RC Jr, Kufe DW, Morton DL, et al. editors. Cancer Medicine, 3rd ed. Philadelphia: Lea \& Febiger; 1993. pp884-96.

97 Basaria S. Androgen deprivation therapy, insulin resistance, and cardiovascular mortality: an inconvenient truth. J Androl 2008; 29: 534-39.

98 Taylor LG, Canfield SE, Du X. Review of major adverse effects of androgen-deprivation therapy in men with prostate cancer. Cancer 2009; 115: 2388-99.

99 Khera M, Grober ED, Najari B, Colen JS, Mohamed O, et al. Testosterone replacement therapy following radical prostatectomy. J Sex Med 2009; 6: 1165-70.

100 Fowler JE, Whimore WF. The response to metastatic adenocarcinoma of the prostate to exogenous testosterone. J Urol 1981; 126: 372-5.

101 Szmulewitz R, Mohile S, Posadas E, Kunnavakkam R, Karrison $\mathrm{T}$, et al. A randomized phase 1 study of testosterone replacement for patients with low-risk castrationresistant prostate cancer. Eur Urol 2009; 56: 97-103.

102 Morris MJ, Huang D, Kelly WK, Slovin SF, Stephenson $\mathrm{RD}$, et al. Phase 1 trial of high-dose exogenous testosterone in patients with castration-resistant metastatic prostate cancer. Eur Urol 2009; 56: 237-44.

103 Niu Y, Chang TM, Yeh S, Ma WL, Wang YZ, et al. Differential androgen receptor signals in different cells explain why androgen-deprivation therapy of prostate cancer fails. Oncogene 2010; 29: 3593-04.

104 Heinlein CA, Chan C. Androgen receptor in prostate cancer. Endocr Rev 2004; 25: 276-308.

105 McCarthy MI, Abecasis GR, Cardon LR, Goldstein DB, Little $\mathrm{J}$, et al. Genome-wide association studies hanfor complex traits: consensus, uncertainty and challenges. Nat Rev Genet 2008; 9: 356-69.

106 Linja MJ, Visakorpi T. Alterations in AR and prostate cancer. J Steroid Biochem Mol Biol 2004; 92: 255-64.

107 Horoszewicz JS, Leong SS, Chu TM, Wajsman ZL, Friedman $\mathrm{M}$, et al. The LNCaP cell line- a new model for studies on human prostatic carcinoma. Models for Prostate Cancer. Alan R. Liss Inc; 1980. pp115-32

108 Gaddipati JP, McLeod DG, Heidenberg HB, Sesterhenn IA, Finger MJ, et al. Frequent detection of codon 877 mutation in the androgen receptor gene in advanced prostate cancers. Cancer Res 1994; 54: 2861-4.

109 Suzuki H, Akakura K, Komiya A, Aida S, Akimoto S, et al. Codon 877 mutation in the androgen receptor gene in advanced prostate cancer: relation to antiandrogen withdrawal syndrome. Prostate 1996; 29: 153-8.

110 Sramkoski RM, Pretlow TG 2nd, Giaconia JM, Pretlow TP, Schwartz S, et al. A new human prostate carcinoma cell line, 22Rv1. In Vitro Cell Dev Biol Anim 1999; 35: 403-9.

111 Hartel A, Didier A, Ulbrich SE, Wierer M, Meyer HH. Characterisation of steroid receptor expression in the human prostate carcinoma cell line 22RV1 and quantification of androgen effects on mRNA regulation of prostate-specific genes. J Steroid Biochem Mol Biol 2004; 92: 187-97.

112 Marcias G, Erdmann E, Lapouge G, Siebert C, Barthélémy P, et al. Identification of novel truncated androgen receptor (AR) mutants including unreported pre-mRNA splicing variants in 
the 22Rv1 hormone-refractory prostate cancer $(\mathrm{PCa})$ cell line. Hum Mutat 2009; 31: 74-80.

113 Koochekpour S, Maresh GA, Katner A, Parker-Johnson $\mathrm{K}$, Lee TJ, et al. Establishment and characterization of a primary African-American prostate cancer cell line, E006AA. Prostate 2004; 60: 141-52.

114 D'Antonio JM, Vander Griend DJ, Lizamma Antony L, Ndikuyeze G, Dalrymple SL, et al. Loss of growth suppression is necessary but not sufficient for prostate cancer cells acquiring oncogene addiction to androgen receptor Signaling. PLoS One. $2010 \mathrm{Jul}$ 8; 5(7): e11475.

115 Liu W, Xie CC, Zhu Y, Li T, Sun J, et al. Homozygous deletions and recurrent amplifications implicate new genes involved in prostate cancer. Neoplasia 2008; 10: 897-907.

116 Zhao XY, Malloy PJ, Krishnan AV, Swami S, Navone NM, et al. Glucocorticoids can promote androgen-independent growth of prostate cancer cells through a mutated androgen receptor. Nat Med 2000; 6: 703-6.

117 Kaplan-Lefko PJ, Chen TM, Ittmann MM, Barrios RJ, Ayala GE, et al. Pathobiology of autochthonous prostate cancer in a pre-clinical transgenic mouse model. Prostate 2003; 55: 219-37.

118 Greenberg NM, DeMayo F, Finegold MJ, Medina D, Tilley WD, et al. Prostate cancer in a transgenic mouse. Proc Natl Acad Sci USA 1995; 92: 3439-43.

119 Han G, Foster BA, Mistry S, Buchanan G, Harris JM, et al. Hormone status selects for spontaneous somatic androgen receptor variants that demonstrate specific ligand and cofactor dependent activities in autochthonous prostate cancer. J Biol Chem 2001; 276: 11204-13.

120 Cussenot O, Valeri A. Heterogeneity in genetic susceptibility to prostate cancer. Eur J Intern Med 2001; 12: 11-6.

121 Smith JR, Foster BA, Mistry S, Buchanan G, Harris JM, et al. Major susceptibility locus for prostate cancer on chromosome 1 suggested by a genome-wide search. Science 1996; 274: 1371-4.

122 Berthon P, Valeri A, Cohen-Akenine A, Drelon E, Paiss $\mathrm{T}$, et al. Predisposing gene for early-onset prostate cancer, localized on chromosome 1q42.2-43. Am J Hum Genet 1998; 62: 1416-24.

123 Gibbs M, Stanford JL, McIndoe RA, Jarvik GP, Kolb S, et al. Evidence for a rare prostate cancer-susceptibility locus at chromosome 1p36. Am J Hum Genet 1999; 64: 776-87.

124 Cancel-Tassin G, Cussenot O. Genetic susceptibility to prostate cancer. BJU Int 2005; 96: 1380-5.

125 Uchida T, Wang C, Sato T, Gao J, Takashima R, et al. BRCA1 gene mutation and loss of heterozygosity on chromosome 17q21 in primary prostate cancer. Int J Cancer 1999; 84: 19-23.

126 Johannsson O, Loman N, Möller T, Kristoffersson U, Borg A, et al. Incidence of malignant tumours in relatives of BRCA1 and BRCA2 germline mutation carriers. Eur J Cancer 1999; 35: $1248-57$.

127 Reichardt JKV, Makridakis N, Henderson BE, Yu MC, Pike $\mathrm{MC}$, et al. Genetic variability of the human SRD5A2 gene: implications for prostate cancer risk. Cancer Res 1995; 55: 3973-5.

128 Feldman D. Androgen and vitamin D receptor gene polymorphisms: the long and short of prostate cancer risk. J Natl Cancer Inst 1997; 89: 109-11.

129 Ingles SA, Ross RK, Yu MC, Irvine RA, La Pera G, et al. Association of prostate cancer risk with genetic polymorphisms in vitamin D receptor and androgen receptor. J Natl Cancer Inst 1997; 89: 166-70.

130 Gruber SB, Chen H, Tomsho LP, Lee N, Perrone EE, et al.
$\mathrm{R} 726 \mathrm{~L}$ androgen receptor mutation is uncommon in prostate cancer families in the United States. Prostate 2003; 54: 306-9.

131 Crocitto LE, Henderson BE, Coetzee GA. Identification of two germline point mutations in the 5' UTR of the androgen receptor gene in men with prostate cancer. J Urol 1997; 158: 1599-601.

132 Mononen N, Syrjäkoski K, Matikainen M, Tammela TL, Schleutker J, et al. Two percent of Finnish prostate cancer patients have a germ-line mutation in the hormone-binding domain of the androgen receptor gene. Cancer Res 2000; 60: 6479-81.

133 Evans BA, Harper ME, Daniells CE, Watts CE, Matenhelia $\mathrm{S}$, et al. Low incidence of androgen receptor gene mutations in human prostatic tumors using single strand conformation polymorphism analysis. Prostate 1996; 28: 162-71.

$134 \mathrm{Hu}$ SY, Liu T, Liu ZZ, Ledet E, Velasco-Gonzalez C, et al. Identification of a novel germline missense mutation of the androgen receptor in African American men with familial prostate cancer. Asian J Androl 2010; 12: 336-43.

135 Visakorpi T, Hyytinen E, Koivisto P, Tanner M, Keinänen R, et al. In vivo amplification of the androgen receptor gene and progression of human prostate cancer. Nat Genet 1995; 9: 401-6.

136 Koivisto P, Kononen J, Palmberg C, Tammela T, Hyytinen $\mathrm{E}$, et al. Androgen receptor gene amplification: a possible molecular mechanism for androgen deprivation therapy failure in prostate cancer. Cancer Res 1997; 57: 314-9.

137 Hyytinen E, Haapala K, Thompson J, Lappalainen I, Roiha M, et al. Pattern of somatic androgen receptor gene mutations in patients with hormone-refractory prostate cancer. Lab Invest 2002; 82: 1591-8.

138 Brown RS, Edwards J, Dogan A, Payne H, Harland SJ, et al. Amplification of the androgen receptor gene in bone metastases from hormone-refractory prostate cancer. J Pathol 2002; 198: 237-44.

139 Haapala K, Hyytinen ER, Roiha M, Laurila M, Rantala I, Helin $\mathrm{HJ}$, et al. Androgen receptor alterations in prostate cancer relapsed during a combined androgen blockade by orchiectomy and bicalutamide. Lab Invest 2001; 81: 1647-51.

140 Hernes EH, Linja M, Fosså SD, Visakorpi T, Berner A, et al. Hormone resistant cancer with symptomatic pelvic tumors: patient survival and prognostic factors. BJU Int 2000; 86: 240-7.

141 Edwards J, Krishna NS, Mukherjee R, Watters AD, Underwood MA, et al. Amplification of the androgen receptor may not explain the development of androgen-independent prostate cancer. BJU Int 2001; 88: 633-7.

142 Miyoshi Y, Uemura H, Fujinami K, Mikata K, Harada M, et al. Fluorescence in situ hybridization evaluation of c-myc and androgen receptor gene amplification and chromosomal anomalies in prostate cancer in Japanese patients. Prostate 2000; 43: 225-32.

143 Bubendorf L, Kononen J, Koivisto P, Schraml P, Moch $\mathrm{H}$, et al. Survey of gene amplifications during prostate cancer progression by high-throughput fluorescence in situ hybridization on tissue microarrays. Cancer Res 1999; 59: 803-6.

144 Zeegers MP, Kiemeney LA, Nieder AM, Ostrer H. How strong is the association between $\mathrm{CAG}$ and GGN repeat length polymorphisms in the androgen receptor gene and prostate cancer risk? Cancer Epidemiol Biomarkers Prev 2004; 13 (11 Pt 1): 1765-71.

145 Lange EM, Sarma AV, Ray A, Wang Y, Ho LA, et al. The androgen receptor CAG and GGN repeat polymorphisms and 
prostate cancer susceptibility in African-American men: results from the Flint Men's Health Study. J Hum Genet 2008; 53 : 220-6.

146 Panz VR, Joffe BI, Spitz I, Lindenberg T, Farkas A, et al. Tandem CAG repeats of the androgen receptor gene and prostate cancer risk in black and white men. Endocrine 2001; 15: 213-6.

147 Dmitrienko A, Chuang-Stein C, D'Agostino R. Pharmaceutical Statistics Using SAS: A Practical Guide. Cary, NC: SAS Press; 2007.

148 Gaston KE, Kim D, Singh S, Ford III OH, Mohler JL. Racial differences in androgen receptor protein expression in men with clinically localized prostate cancer. J Urol 2003; 170: 990-3.

149 Harper ME, Pike A, Peeling WB, Griffiths K. Steroids of adrenal origin metabolized by human prostatic tissue both in vivo and in vitro. J Endocrinol 1974; 60: 117-25.

150 Veldscholte J, Ris-Stalpers C, Kuiper GG, Jenster G, Berrevoets $\mathrm{C}$, et al. A mutation in the ligand binding domain of the androgen receptor of human LNCaP cells affects steroid binding characteristics and response to anti-androgens. Biochem Biophys Res Commun 1990; 173: 534- 40.

151 Veldscholte J, Berrevoets CA, Brinkmann AO, Grootegoed JA, Mulder E. Anti-androgens and the mutated androgen receptor of LNCaP cells: differential effects on binding affinity, heat-shock protein interaction, and transcription activation. Biochemistry 1992; 31: 2393-9.

152 Freedman ML, Pearce CL, Penney KL, Hirschhorn JN, Kolonel LN, et al. Systematic evaluation of genetic variation at the androgen receptor locus and risk of prostate cancer in a multiethnic cohort study. Am J Hum Genet 2005; 76: 82-90.

153 Culig Z, Hobisch A, Cronauer MV, Cato AC, Hittmair A, et al. Mutant androgen receptor detected in an advanced-stage prostatic carcinoma is activated by adrenal androgens and progesterone. Mol Endocrinol 1993; 7: 1541-50.

154 Avancès $\mathrm{C}$, Georget $\mathrm{V}$, Térouanne $\mathrm{B}$, Orio $\mathrm{F}$, Cussenot $\mathrm{O}$, et al. Human prostatic cell line PNT1A, a useful tool for studying androgen receptor transcriptional activity and its differential subnuclear localization in the presence of androgens and antiandrogens. Mol Cell Endocrinol 2001; 184: 13-24.

155 Quarmby VE, Kemppainen JA, Sar M, Lubahn DB, French FS, et al. Expression of recombinant androgen receptor in cultured mammalian cells. Mol Endocrinol 1990; 4: 399-407.

156 Klocker H, Kaspar F, Eberle J, Uberreiter S, Radmayr C, et al. Point mutation in the DNA binding domain of the androgen receptor in two families with Reifenstein syndrome. Am J Hum Genet 1992; 50: 1318-27.

157 Flaman JM, Frebourg T, Moreau V, Charbonnier F, Martin $\mathrm{C}$, et al. A simple p53 functional assay for screening cell lines, blood, and tumors. Proc Natl Acad Sci USA 1995; 92: 3963-7.

158 van Oijen MG, Slootweg PJ. Gain-of-function mutations in the tumor suppressor gene p53. Clin Cancer Res 2000; 6: 2138-45.

159 Shi XB, Di Mauro SM, Highshaw R, Deitch AD, Evans CP, et al. Application of a yeast assay to detect functional p53 mutations in archival prostate cancer tissue. Cancer Biother Radiopharm 2002; 17: 657-64.

160 Koochekpour S, Lee TJ, Wang R, Culig Z, Delorme N, et al. Prosaposin upregulates AR and PSA expression and activity in prostate cancer cells (LNCaP). Prostate 2007; 67: 178-89.

161 Koochekpour S, Lee TJ, Sun Y, Hu S, Grabowski GA, et al. Prosaposin is an AR-target gene and its neurotrophic domain upregulates $\mathrm{AR}$ expression and activity in prostate stromal cells. J Cell Biochem 2008; 104: 2272-85.

162 Koochekpour S, Lee TJ, Wang R, Sun Y, Delorme N, et al. Prosaposin is a novel androgen-regulated gene in prostate cancer cell line LNCaP. J Cell Biochem 2007; 101: 631-41.

163 Schoenberg MP, Hakimi JM, Wang S, Bova GS, Epstein JI, et al. Microsatellite mutation (CAG24-->18) in the androgen receptor gene in human prostate cancer. Biochem Biophys Res Commun 1994; 198: 74-80.

164 Newmark JR, Hardy DO, Tonb DC, Carter BS, Epstein JI, et al. Androgen receptor gene mutations in human prostate cancer. Proc Natl Acad Sci USA 1992; 89: 6319-23.

165 Watanabe M, Ushijima T, Shiraishi T, Yatani R, Shimazaki $\mathrm{J}$, et al. Genetic alterations of androgen receptor gene in Japanese human prostate cancer. Jpn J Clin Oncol 1997; 27: 389-93.

166 Segawa N, Nakamura M, Shan L, Utsunomiya H, Nakamura Y, et al. Expression and somatic mutation on androgen receptor gene in prostate cancer. Int J Urol 2002; 9: 545-53.

167 Thompson J, Hyytinen ER, Haapala K, Rantala I, Helin HJ, et al. Androgen receptor mutations in high-grade prostate cancer before hormonal therapy. Lab Invest 2003; 83: 1709-13.

168 Elo JP, Kvist L, Leinonen K, Isomaa V, Henttu P, et al. Mutated human androgen receptor gene detected in a prostatic cancer patient is also activated by estradiol. J Clin Endocrinol Metab 1995; 80: 3494-500.

169 Taplin ME, Rajeshkumar B, Halabi S, Werner CP, Woda BA, et al. Androgen receptor mutations in androgen-independent prostate cancer: cancer and leukemia group B study 9663. J Clin Oncol 2003; 21: 2673-8.

170 Taplin ME, Bubley GJ, Ko YJ, Small EJ, Upton M, et al. Selection for androgen receptor mutations in prostate cancers treated with androgen antagonist. Cancer Res 1999; 59: 2511-5.

171 Lamb DJ, Puxeddu E, Malik N, Stenoien DL, Nigam R, et al. Molecular analysis of the androgen receptor in ten prostate cancer specimens obtained before and after androgen ablation. J Androl 2003; 24: 215-25.

172 Palmberg C, Koivisto P, Kakkola L, Tammela TL, Kallioniemi $\mathrm{OP}$, et al. Androgen receptor gene amplification at primary progression predicts response to combined androgen blockade as second line therapy for advanced prostate cancer. J Urol 2000; 164: 1992-5.

173 Ruizeweld de Winter JA, Janssen PJ, Sleddens HM, VerleunMooijman MC, Trapman J, et al. Androgen receptor status in localized and locally progressive hormone-refractory prostate cancer. Am J Pathol 1994; 144: 735-46.

174 Wallen MJ, Linja M, Kaartinen K, Schleutker J, Visakorpi T. Androgen receptor gene mutations in hormone-refractory prostate cancer. J Pathol 1999; 189: 559-63.

175 Taplin ME, Bubley GJ, Shuster TD, Frantz ME, Spooner AE, et al. Mutation of the androgen-receptor gene in metastatic androgen-independent prostate cancer. N Engl J Med 1995; 332: 1393-8.

176 Gregory CW, Johnson RT Jr, Mohler JL, French FS, Wilson EM. Androgen receptor stabilization in recurrent prostate cancer is associated with hypersensitivity to low androgen. Cancer Res 2001; 61: 2892-8.

177 Zhao XY, Boyle B, Krishnan AV, Navone NM, Peehl DM, et al. Two mutations identified in the androgen receptor of the new human prostate cancer cell line MDA PCa 2a. J Urol 1999; 162: 2192-9. 